\title{
Considerations of Antibody Geometric Constraints on NK Cell Antibody Dependent Cellular Cytotoxicity
}

\author{
Charles D. Murin* \\ Department of Integrative Structural and Computational Biology, Scripps Research, La Jolla, CA, United States
}

It has been well-established that antibody isotype, glycosylation, and epitope all play roles in the process of antibody dependent cellular cytotoxicity (ADCC). For natural killer (NK) cells, these phenotypes are linked to cellular activation through interaction with the lgG receptor Fc $\gamma$ RIIlla, a single pass transmembrane receptor that participates in cytoplasmic signaling complexes. Therefore, it has been hypothesized that there may be underlying spatial and geometric principles that guide proper assembly of an activation complex within the NK cell immune synapse. Further, synergy of antibody phenotypic properties as well as allosteric changes upon antigen binding may also play an as-of-yet unknown role in ADCC. Understanding these facets, however, remains hampered by difficulties associated with studying immune synapse dynamics using classical approaches. In this review, I will discuss relevant NK cell biology related to ADCC, including the structural biology of Fc gamma receptors, and how the dynamics of the NK cell immune synapse are being studied using innovative microscopy techniques. I will provide examples from the literature demonstrating the effects of spatial and geometric constraints on the T cell receptor complex and how this relates to intracellular signaling and the molecular nature of lymphocyte activation complexes, including those of NK cells. Finally, I will examine how the integration of high-throughput and "omics" technologies will influence basic NK cell biology research moving forward. Overall, the goal of this review is to lay a basis for understanding the development of drugs and therapeutic antibodies aimed at augmenting appropriate NK cell ADCC activity in patients being treated for a wide range of illnesses.

Keywords: antibody, ADCC, NK cell, structural biology, antibody therapeutics, immune synapse, antibody effector functions, immune signaling

\section{INTRODUCTION}

Antibodies have a bifunctional role within the immune system. This role is physically built into their structure through two parts: the fragment antigen binding (Fab), for recognizing antigen, and the fragment crystallizable $(\mathrm{Fc})$, for recruiting effector immune cells. The process by which antibody-coated cells direct effector cells to attack and kill an opsonized target is known as antibody dependent cellular cytotoxicity (ADCC). This is accomplished through ligation with Fc gamma receptors (Fc $\gamma$ Rs), which forms a conduit of communication between the target cell (TC) and immune effector cell (1). The Fc $\gamma$ Rs are an assortment of transmembrane receptors expressed to varying levels on primarily innate, but also some adaptive, immune cells (2). 
The ability of antibodies to recruit ADCC is a highly desirable trait for therapeutic and vaccine development, and NK cells are of central focus due to their proclivity for ADCC and as a front-line defense immune cell (3-6). While our understanding of antigenantibody recognition and $\mathrm{Fc}-\mathrm{Fc} \gamma \mathrm{R}$ interaction are each quite extensive in isolation, there is still a gap in knowledge about how these two important aspects of antibodies interplay, especially in vivo. Combined with frequent incongruency between available in vitro and in vivo data regarding antibody effector function as well as the generally complicated nature of the human immune system, we are left with a looming question: what makes an effective antibody for recruiting NK cell ADCC?

Answering the question above requires a much better understanding of the underlying molecular basis of antibody and cellular effector functions. A good place to start is at the point of initial contact between an NK cell and TC, known as the immune synapse (IS). This is the point where activating receptors on the NK cell surface bind to the Fc domain of antigen-engaged antibodies and initialize a cascade of events that lead to NK cell activation and ultimately target-cell death. Extensive studies of the $\mathrm{T}$ cell receptor have provided valuable insight into the organization of the T cell IS (7-10), but much less is known about the NK cell immune synapse (NKIS).

Antibodies are necessary for clustering activating receptors in the early stages of ADCC. Structural biology has been instrumental in providing a much more detailed view of this initial interaction of antibody and antigen, especially in the context of viral antigens from HIV, influenza and ebolavirus. Depending on the location of antibody epitopes, the Fc domain of the antibody can differ vastly in how it is presented to a surveying NK cell. Many other variables, including antigen shape, size, and density as well as lipid environment and mobility, can also affect Fc presentation. Further, all these variables can change with antibody isotype, subclass and glycosylation as well as Fc $\gamma \mathrm{R}$ isotype, cellular subclass, Fc $\gamma \mathrm{R}$ expression and diversity as well as Fc $\gamma$ R glycosylation and alleles (2).

With an increasing number of antibody therapeutics, vaccines and immunotherapies entering the clinical market (11), a greater understanding of NK cell mediated ADCC will guide precision medicine and create more effective drugs. In this review, I will focus on current efforts to understand NK cell ADCC, with a particular focus in the context of virally infected cells. I will explore how advances in microscopy techniques as well as the increasing accessibility of big data technologies such as transcriptomics, proteomics, and metabolomics are challenging our understanding of classical immunology and paving a way to fill the gap between in vitro and in vivo observations. Such advances will reveal new avenues for vetting therapeutics with the greatest chance of success in patients.

\section{RECEPTORS AND LIGANDS INVOLVED IN ADCC}

Humans employ an arsenal of a Fc $\gamma$ Rs that specifically recognize antibodies via their Fc domains $(1,2,12)$. These receptors can be inhibitory or activating for the cells on which they reside, denying or providing the initial spark to perform antibodybased effector functions, respectively. While NK cells almost exclusively utilize a single type of activating $\operatorname{Fc} \gamma \mathrm{R}(13,14)$, it is important to understand the function of Fc $\gamma$ Rs more broadly. In this section, I will briefly discuss what is currently known about the receptors and ligands involved in ADCC as well as how their interplay differs among peripheral and tissue resident NK cells.

\section{The Fc $\gamma$ Rs and Their Antibody Ligands}

Each antibody isotype has its own unique Fc receptor, and these have been studied extensively and reviewed elsewhere $(1,12,15)$. The receptors include Fc alpha receptor I (FcaRI or CD89) for immunoglobulin (Ig) A (16-18), Fc epsilon receptor $\mathrm{I}(\mathrm{Fc \varepsilon RI})$ for $\operatorname{IgE}(19-21), \mathrm{Fc} \gamma \mathrm{R}$ for $\operatorname{IgG}(1,12)$ and $F c m u$ receptor $\left(F_{c} \mu R\right)$ for $\operatorname{IgM}(22,23)$. There is also mixed evidence of a putative receptor for soluble $\mathrm{IgD}$, named $\mathrm{Fc}$ delta receptor $(\mathrm{Fc} \partial \mathrm{R})(24,25)$. There are additional Ig receptors that reside on other cell types, including the neonatal $\mathrm{Fc}$ receptor $(\mathrm{FcRn})$ with a function in recycling antibodies $(26,27)$, the mixed $\mathrm{Fc}$ alpha/mu receptor $(\mathrm{Fc} \alpha / \mu \mathrm{R})$ with a function in endocytosis of $\operatorname{IgA} / \operatorname{IgM}$ coated microbes (28) and the polymeric Ig receptor with a function in the endocytosis of polymeric IgA and immune complexes (pIgR) (29, 30). Not all antibodies bind to their cognate receptors with equal affinity (31) and each receptor has a unique control over the immune response.

Most antibody therapeutics are overwhelmingly of the IgG class, which is the primary type of antibody formed in response to vaccines and pathogenic threats $(32,33)$. IgG also makes up a significant portion of the antibodies in human sera to assist the innate immune response in identifying immediate threats and assisting the adaptive memory response. IgGs exist in four known subclasses in humans, including IgG1, IgG2, IgG3, and IgG4 (Figure 1A). There are six known IgG receptors, including Fc $\gamma$ RI (or CD64), Fc $\gamma R I I a / b / c$ (or CD32), and Fc $\gamma$ RIIIa/b (or CD16) (Figure 1B), and they each display differential binding affinity for these subclasses of $\operatorname{IgG}(1,2,31)$. Most of Fc $\gamma$ Rs are activating, signaling through immunoreceptor tyrosine-based activation motifs (ITAMs), with the exception of Fc $\gamma$ RIIb, which is an inhibitory receptor and signals through an immunoreceptor tyrosine-based inhibitory motif (ITIM). Fc $\gamma$ RIIIa is the most abundant and important receptor on NK cells for inducing ADCC, and is a prototypic cell marker for mature NK cells in the periphery (34-36). While all the IgGs can bind to Fc $\gamma$ RIIIa, IgG1 and IgG3 are the most effective at activating NK cells for $\operatorname{ADCC}(2,31)$. Fc $\gamma$ RI has the highest affinity for IgG, particularly IgG1 and IgG3, but is not reported to be found on NK cells (1). Interestingly, there are glycan variants of Fc $\gamma$ RIIIa that display affinities close to Fc $\gamma$ RI, as I will discuss below (37).

Structural biology has been important in elucidating the molecular nature of the $\mathrm{Fc} \gamma \mathrm{R}-\mathrm{Fc}$ interaction and examples exist of every human $\mathrm{Fc} \gamma \mathrm{R}$ both liganded to $\mathrm{Fc}$ and unliganded (Figure 1C) (38). Fc $\gamma$ Rs are quite small and are therefore almost exclusively studied by crystallography (12). Small proteins $(<100 \mathrm{kDa})$ are still difficult targets for cryo-electron 

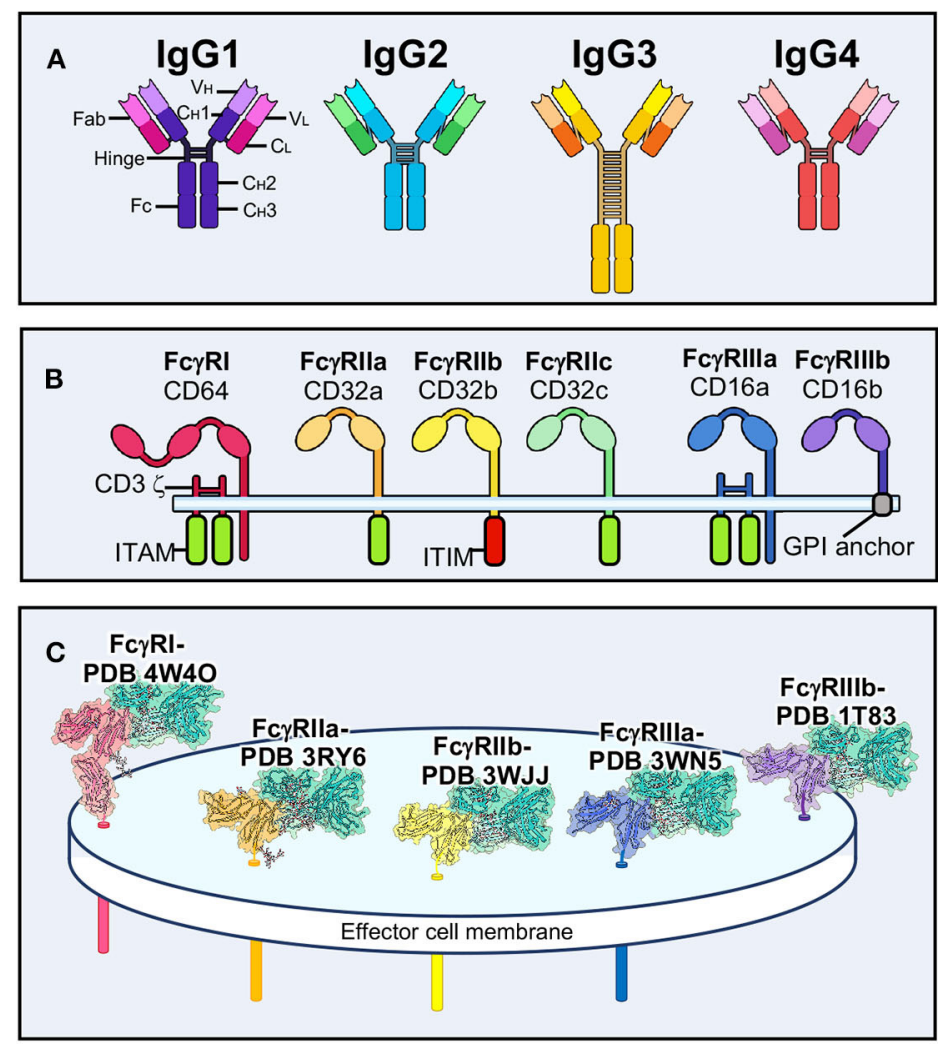

FIGURE 1 | Structural characteristics of antibody-FcyR interactions. (A) Schematic of the four IgG antibody isotypes. IgG domains and sub-domains are labeled on the far left. (B) Schematic of the six human Fc $\gamma R s$ and associated signaling motifs. (C) Structural examples of the five main human Fc $\gamma R s$ bound to Fc domains with transmembrane domains modeled in the effector cell membrane. (D) Conserved features of FcyR-Fc binding. The example shown is of FcyRIlla (PDB 3WN5). ITAM, immunoreceptor tyrosine-based activation motif; ITIM, immunoreceptor tyrosine-based inhibitory motif; GPI, glycosylphosphatidylinositol. microscopy (EM) but are becoming increasingly approachable as technology improves (39-41). These receptors adopt an Iglike fold, similar to antibodies, with two Ig lobes separated by a short elbow (12). Notably, Fc $\gamma$ RI has an additional Ig domain, although the function of the third domain is unclear (42).

These structures have shown striking conservation in how IgGs bind to Fc $\gamma$ Rs (Figure 1D). The majority of molecular interactions occur near the hinge-region of IgG, near the base of the Fc, and are heavily reliant upon a glycan at Asn 297 in the Fc domain $(1,42-44)$. Binding induces asymmetry within the $\mathrm{Fc}$ through interaction with a single domain of $\mathrm{Fc} \gamma \mathrm{Rs}$. Despite Fc domains having two equivalent binding sites for Fc $\gamma$ Rs, binding to IgGs is monovalent, due to this induced asymmetry. The 1:1 stoichiometry of binding is the same for other FcRs, except for Fc $\alpha$ R, which is capable of binding IgA as a dimer (18).

IgG glycosylation can take on many different forms and has major implications for the immune response $(45,46)$. Afucosylated forms of IgG, for example, are capable of a superior ADCC phenotype and structural evidence indicates that this form of IgG allows for a stronger interaction with
Fc $\gamma$ RIIIa (47-49). Fc $\gamma$ Rs are themselves glycosylated to varying degrees (50). Glycosylation is often overlooked in the structural context, due to limitations of crystallography, but has a notable influence on activation and affinity and continues to be explored (37).

\section{Cellular and Tissue Distribution of Fc $\gamma$ Rs}

Fc $\gamma$ Rs exist mainly on immune cells, but have also been found in some neural cells, liver cells and even as part of viral and bacterial defense mechanisms (51). In terms of immunity, the Fc $\gamma$ Rs clearly dominate in innate immune cells, likely due to their role in first-line defense and surveillance (Figure 2A). Conversely, there is little evidence for constitutive $\mathrm{F} c \gamma \mathrm{R}$ expression within adaptive immune cells such as $\mathrm{T}$ cells (although some small subset may express Fc $\gamma$ RIIIa) and only the presence of the inhibitory receptor Fc $\gamma$ RIIb on B cells $(1,51)$. Nevertheless, $\mathrm{Fc} \gamma \mathrm{R}$ activation by antibodies can recruit the adaptive immune response and other innate cells, and thus ties both arms of the immune system together (Figure 2A). Within the innate cell repertoire, macrophages, monocytes, granulocytes, dendritic cells, and mast cells all express varying combinations of the Fc $\gamma$ Rs (1, 51). The expression of some receptors can be 
A

Stem cell

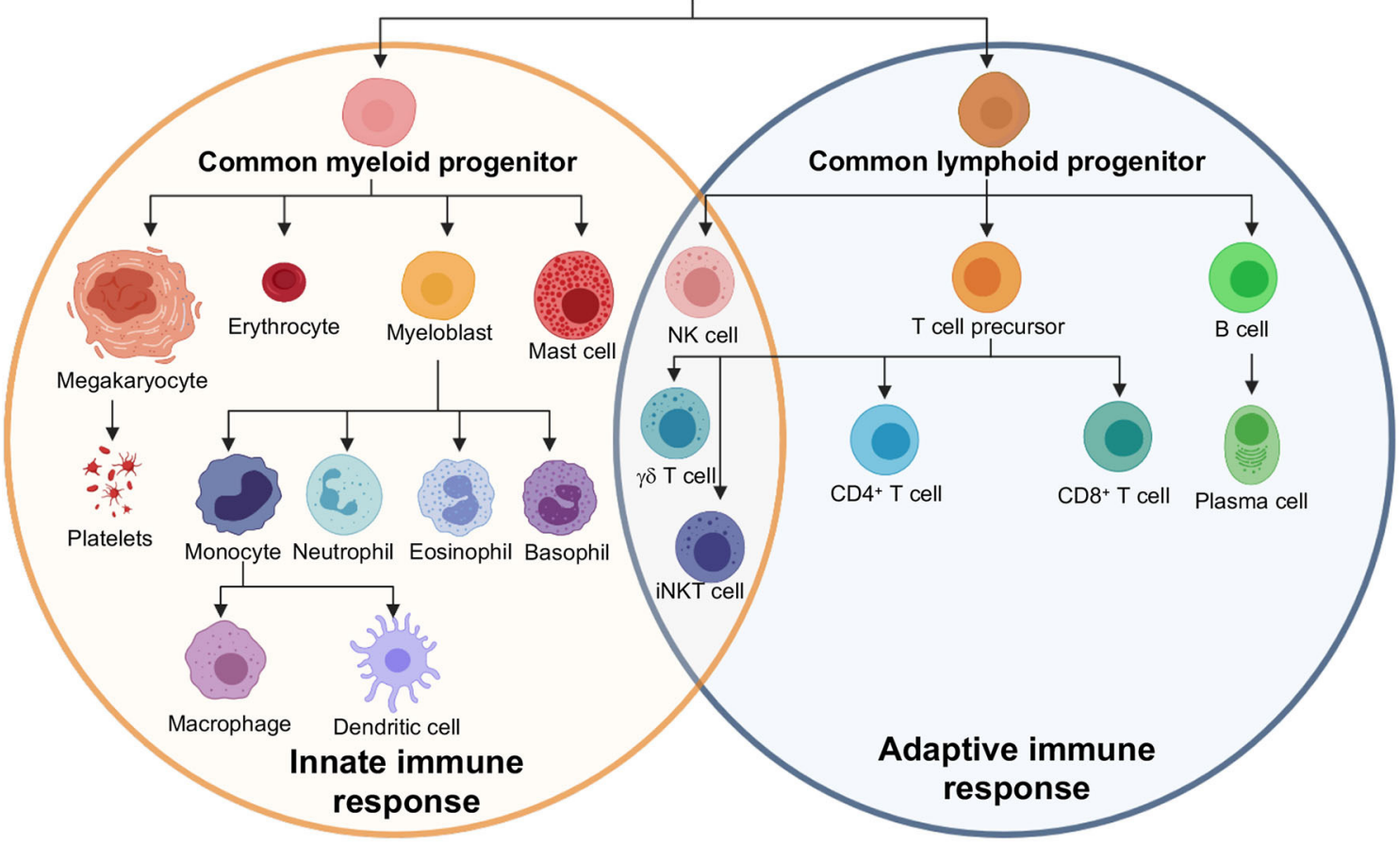

B

Bone marrow

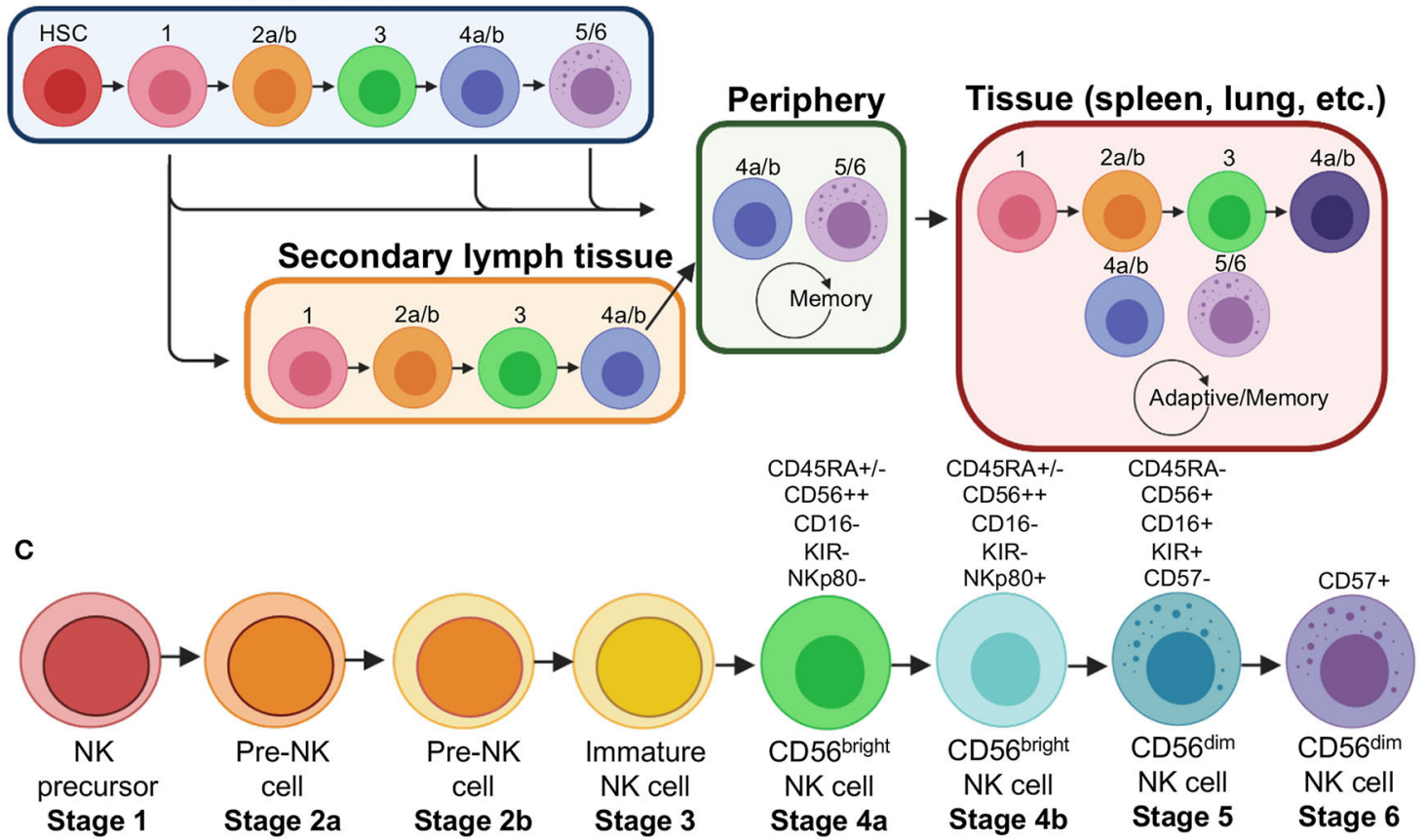

FIGURE 2 | Natural killer cell lineage and development. (A) Immune effector cell lineages showing that NK cells derive from a common lymphoid progenitor related to $\mathrm{B}$ and $\mathrm{T}$ cells, that make up a majority of the adaptive immune response. NK cells, however, share several similarities in function and phenotype to myeloid progenitor cells that make up a majority of the innate immune response. (B) Flow chart showing the modern theory of NK cell development, which demonstrates that NK cells may leave bone marrow at various stages and continue development into specialized subsets in the secondary lymph tissue, peripheral blood or become tissue resident NK cells. (C) Stages of NK cell development, including distinct sub-stages, with major markers that distinguish mature cell types indicated. HSC, hematopoietic stem cell; iNKT, invariant natural killer T cell. 
induced in certain cellular populations, although typically at low levels, or may exist only in a subset of cellular populations. This range of $\mathrm{Fc} \gamma \mathrm{R}$ expression on immune cells is not wellunderstood but may serve as an advantage to the immune system in being able to quickly respond to a diverse array of insults.

NK cells form a unique cellular subset since they are of the lymphoid lineage, more closely related to $\mathrm{B}$ and $\mathrm{T}$ cells, but act more like an innate immune cell in their function, are therefore often referred to as innate lymphoid cells or ILCs (Figure 2A) (52-54). NK cells are exceptionally diverse, and I will briefly discuss both their presence in peripheral blood (PB) and tissues (Figure 2B) (55-59). NK cells form a smaller fraction of lymphocytes within the PB but can vary widely from 5 to $20 \%$ or even higher depending on the individual. Typically, peripheral NK cells are defined by a lack of CD3 to distinguish them from T cells, a lack of CD19 to distinguish them from B cells, and the presence of CD45 to distinguish them as lymphocytes. Further, NKs are confirmed by the presence of CD56 and CD16 to varying degrees, leading to so called CD $56^{\text {bright }} / \mathrm{CD} 16^{\mathrm{lo} /-}$ and CD $56^{\mathrm{dim}} / \mathrm{CD} 16^{+}$populations (Figure 2C) $(60,61) .{\text { CD } 56^{\mathrm{dim}} \mathrm{NK}}^{\mathrm{a}}$ cells are thought to be the cellular population that is best at performing ADCC due to a higher constitutive expression of CD16. This makes CD56 ${ }^{\mathrm{dim}}$ NK cell lines, such as NK-92 cells, particularly desirable for $\mathrm{NK}$ cell engineering and use in in vitro ADCC assays $(62,63)$. CD56 ${ }^{\text {bright }} \mathrm{NK}$ cells can respond rapidly to produce cytokines and chemokines in conjunction with the response of other activated cells, including $\mathrm{T}$ cells, dendritic cells and monocytes.

The diversity of NK cells extends to tissue resident NK cells (Figure 2B) $(34,57,64)$. CD $56^{\mathrm{dim}} \mathrm{NK}$ cells, which predominate the $\mathrm{ADCC}$ response in $\mathrm{PB}$, are not found ubiquitously in all tissues and may actually be outnumbered by CD56 ${ }^{\text {bright }}$ cells overall in the human body $(57,64)$. The population of CD56 $6^{\mathrm{dim}}$ cells capable of ADCC largely exist in the bone marrow as well as lung, spleen, breast and subcutaneous adipose tissue (57). NK cell diversity is extended by varying degrees of chemokine receptors as well as a huge variety of killer immunoglobulin-like receptors (KIRs) (65). This plasticity specializes NK cells to their environment and makes them functionally distinct (Figure 2B). Further, certain NK cells may even develop memory, similar to adaptive immune cells $(66,67)$.

\section{Limits to Our Current Understanding of Antibody-Fc $\gamma \mathbf{R}$ Interactions}

There are many gaps that prevent a full understanding of antibody-Fc $\gamma \mathrm{R}$ interactions. First, all of our molecular observations of antibody-Fc $\gamma \mathrm{R}$ interactions come from fragments. For example, in every structure of Fc $\gamma$ Rs, the IgG is severed from the antigen recognition domains (Figure 1C). Conversely, in every structure of antibody bound to antigen, the $\mathrm{Fc}$ fragment is missing. While there are a few structures of IgGs alone, as well as biophysical characterization that demonstrate their range of flexibility and overall architecture, this flexibility has largely restricted their study in complexes due to historical limitations in structural biology (68).

Next, Fc $\gamma$ Rs are after all membrane glycoproteins, but there are no structures of the full-length receptors. Additionally, many activating receptors use transmembrane adaptors that are necessary for cell surface expression and signaling, proteins that have only limited structural observation in isolation $(14,69,70)$. While Fc $\gamma$ Rs are mostly single pass transmembrane proteins (with the exception of Fc $\gamma$ RIIIb, which is a GPI-anchored protein and whose signaling is not well-understood), there are almost certainly higher order assemblies that must form in order for signaling to proceed.

Finally, known molecular observations have not yet been reconciled with the crowded but organized environment of the IS. Most of our understanding of the NKIS has derived from in vitro studies outside of a living organism. Although reductionists approaches are necessary as building blocks, these observations must begin to be placed back into a larger context. Below, I will further explore what is involved in the assembly and function of the NKIS in the context of ADCC and how we have amassed this knowledge.

\section{SHEDDING "LIGHT" ON NKIS DYNAMICS}

The term "synapse" refers to a junction between cells and is most often used to describe the junction between neurons. This definition has since been expanded to also describe the junction between immune cells and TCs (71-73). While most notably used to describe the T cell IS (72), the term has more recently been expanded to NK cells (74). In both cases, the IS is a delicate ballet of receptors and ligands, cytoskeletal rearrangements and exchange of cytotoxic material in order to specifically destroy a cell deemed a threat. Understanding the players in this immunological dance and how they dynamically move through the process of immunological attack is vital to understanding ADCC and how antibodies affect the process and outcome.

The NKIS can be likened to a busy street corner at rush hour, people and cars crisscrossing and making their way to destinations in a concerted spatio-temporal fashion. Similarly, within the IS, receptors and cell surface molecules must bind to their ligands, signal and move to make way for the next set of molecules to follow suit. Understandably, evaluating the role of an antibody in this context can be extremely challenging. Do we use the detailed approaches of biochemistry and structural biology, medium resolution approaches provided by light microscopy, or more global "omics" types of big data acquisition and analysis? Ideally, details could be obtained equally from any one technique; however, technology has been historically limiting and complete understanding will require integration of all these techniques. In this section, I will provide a general overview of what is known to occur during formation of the NKIS, specifically during ADCC, and how structural biology and light microscopy have brought complementary understanding to this process. 


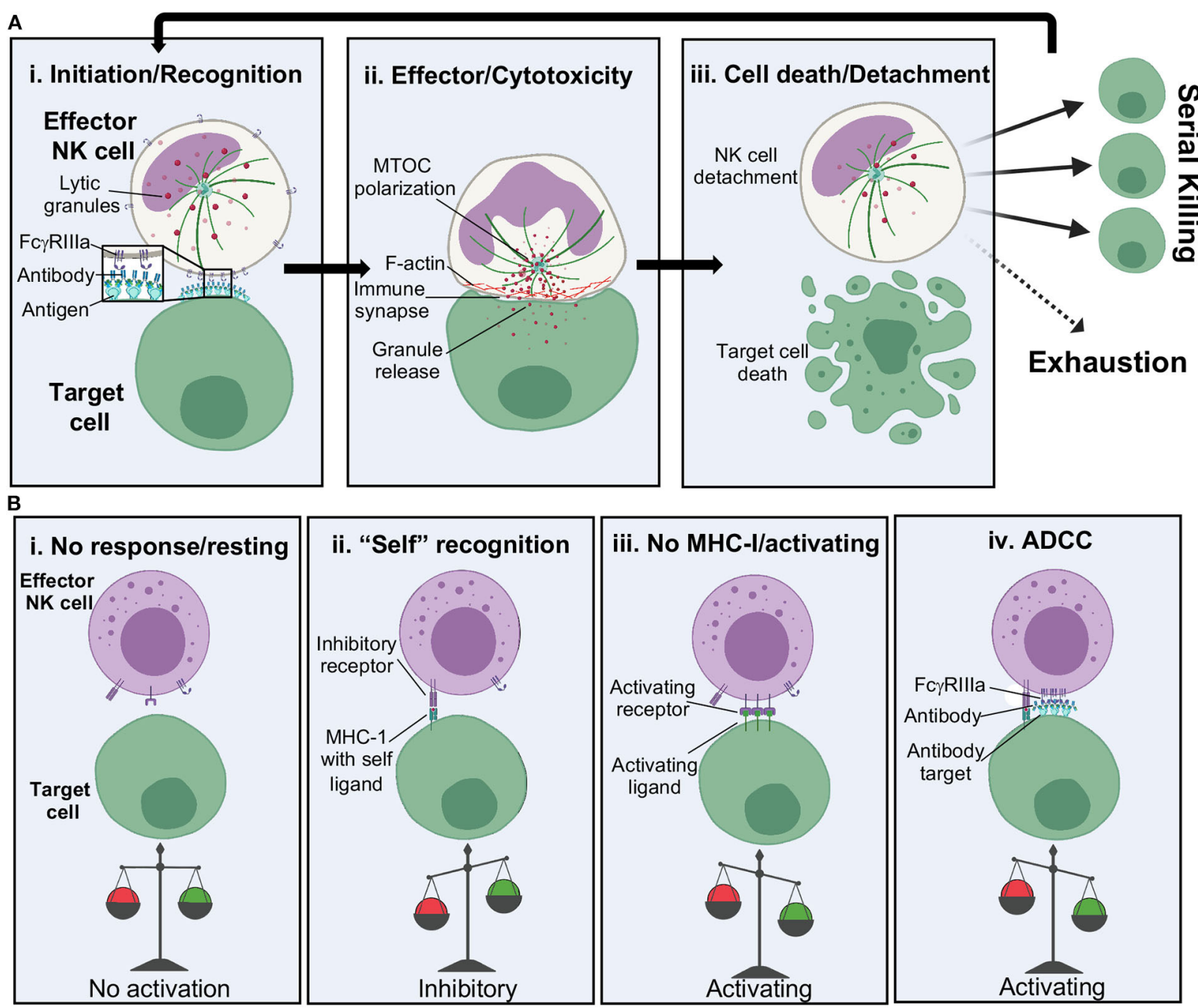

FIGURE 3 | NK cell cytolytic activation. (A) Stages of NK cell cytolytic activity including: (i) tethering of effector to target cell and receptor binding, (ii) lytic granule and actin polarization at the immune synapse and release of lytic granules into target cells, and (iii) target cell death and release of the NK cell. NK cells can go on to serially kill or become exhausted. (B) NK cell activation relies upon a balance of activating and inhibitory signals. MHC, major histocompatibility complex.

\section{ADCC and the NKIS}

The NKIS has been previously studied in detail and the general stages well laid out (Figure 3A) (74-77). There are several different types of NKISs (78), but we will focus mainly on the lytic IS here. In every type of synapse, the initial stages are the same, which is that of surveillance (Figure 3Ai). The process of surveillance involves the tethering of effector to target cell followed by adhesion. Each of these events is not completely wellunderstood, but likely involves carbohydrate sensing by $\mathrm{CD} 2$ (79), selectins like L-selectin (80) and integrins like CD11a/b and CD18 (77), which are upregulated and cluster early in the NKIS (77). These initial steps serve as way to lock effector and target cells together to then proceed to recognition, although some level of pre-activation occurs.

Following attachment to a target cell, it is time for the NK cell to decide: friend or foe? (Figure 3Ai) Since NK cells are primed to respond quickly and harshly to threats, their activation relies upon a well-controlled balance of activating and inhibitory signals (Figure 3B). Recognition of major histocompatibility complex I (MHC-I) bearing "self" peptides is an important part of this decision but can be overcome by stress signals. For example, certain cancers cause upregulation of stress signals such as MHC class I chain-related protein A/B (MICA and MICB) and UL16-binding (ULBP16) family proteins, which are recognized by the activating NK cell receptor natural-killer group 2, member D (NKG2D), leading to direct killing (81). Further, downregulation of MHC-I can occur during viral infection, also leading to direct killing of infected cells $(82,83)$. The presence of antibody coated cells can also lead to activation by ADCC. For ADCC to occur, surface expressed Fc $\gamma$ RIIIa will recognize antibody bound to the surface of a TC (84), causing the formation of microclusters (85-87). This may be in part aided by concurrent cytoskeletal rearrangements, such as Factin rearrangement, that is thought to aid in the clustering 
of receptors $(76,77,88,89)$ as well as the presence of lipid rafts to assist in fluidity $(90,91)$. Such rearrangements set the stage for microtububle polarization and delivery of lytic granules present throughout the NK cell cytoplasm to a conduit point (Figure 3Aii). Lytic granules bring CD107a to the openings in actin networks and are a tell-tale sign of NK cell activation and cytotoxicity $(89,92)$.

The release of perforin and granzymes at the synaptic cleft, the point of release of lytic granules, starts to signal the end of ADCC and cytotoxicity (Figure 3Aiii) (93). How the NK cell concludes cytotoxicity is still not well-understood, but proteolytic cleavage and shedding of Fc $\gamma$ RIIIa ectodomains is thought to contribute to NK cell release (94). Although NK cells have been shown to serially kill multiple targets in a matter of hours, continued stimulation of ADCC via Fc $\gamma$ RIIIa can exhaust the NK cell leading to decreased perforin release over time and a slower recovery of Fc $\gamma$ RIIIa expression on the surface of NK cells (93-95). Serial killing can proceed until granzyme stores are out, leading to upregulation of CD95L, the ligand for target cell death receptors, resulting in slower apoptosis-mediated killing (96).

In addition to the formation and function of an IS, NK cells also release cytokines and chemokines that can exert effector activity on target cells and help recruit other effector cells, such as macrophages, dendritic cell and $\mathrm{T}$ cells as well as the proliferation of additional NK cells (97-99). Such cascades of activity all stem from the initial stages of antibody binding. Thus, elucidating the molecular basis of antibody-based activation of NK cells is fundamental to understanding the regulation of all downstream processes.

\section{Structural Biology as a Tool to Study the IS}

Structural biology has been a key driver in our understanding of antibody interactions with both antigen and Fc-receptors. Crystallography has long dominated our understanding of Fab-antigen interactions. More recently, single particle cryo-EM has been increasingly important for determining antibody interactions, including more biologically relevant constructs of antigens and difficult targets. For example, cryo-EM is superbly suited to handle sample heterogeneity, enabling the structural analysis of diverse polyclonal antibody epitopes in a single imaging experiment. This technique has been instrumental in understanding the antibodybased immune response to viral infection as well as novel vaccines $(100,101)$.

In terms of epitope mapping, the field of infectious disease has exemplary examples of survivor-derived monoclonal antibodies bound to viral entry-associated proteins, which my colleagues and I recently reviewed (102). Such examples include, but are not limited to, HIV, influenza, ebolaviruses, marburgviruses, SARS, MERS, Hepatitis, Chikungunya virus, Zika virus, Dengue virus and Noroviruses, among many others. Antibodies are capable of binding to nearly any epitope presented on enveloped viral antigens (Figure 4), however their capacity to induce ADCC varies widely (103-105). The reason for such variance is unknown but may be related to where an epitope is located and the way in which an antibody binds, as well as genetic

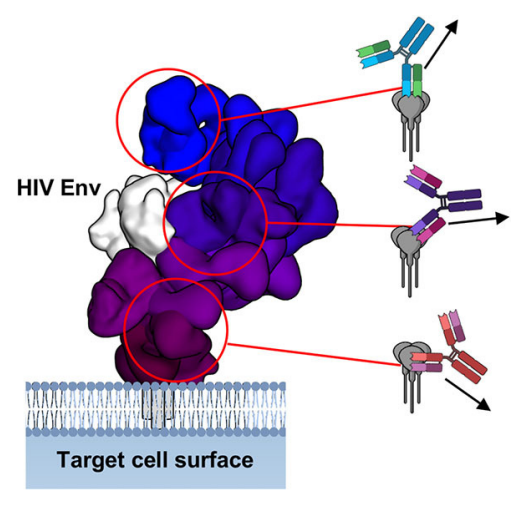

FIGURE 4 | Fab-antigen structures give clues to antibody Fc presentation. Overlay of structures of Fab-HIV Env interaction, demonstrating a wide range of antibody angles-of-approach. On the right are schematics of how the full $\lg$ Gould bind and the direction in which the Fc may point toward approaching effector cells. Figure adapted from Murin et al. (102).

variation in Fc $\gamma$ Rs (106). The Fab alone bound to antigen can give clues to how the $\mathrm{Fc}$ may be situated and how this relates to receptor binding and macromolecular complex assembly (Figure 4).

By far the most important contributor to antibody ADCC activity studied so far is antibody subclass and glycosylation. While the basis of subclass remains somewhat of a mystery, we do have substantial evidence as to the importance of Fc glycosylation $(43,47,49,105,107,108)$. Specifically, if the glycan at Asn 297 is fucosylated, then the binding to Fc $\gamma$ RIIIa is impaired $(43,47-49,109)$. With removal of this core fucose, however, affinity is bolstered to the low nanomolar level. Further affinity can be gained from di-sialylated, complex glycans lacking core fucose, which also have strong anti-inflammatory properties $(107,108,110)$. Nuclear magnetic resonance (NMR) studies suggest that the type of glycan attached to the Fc modulates Fc dynamics as well through the C'E loop that contains Asn 297 (111, 112). Conversely, Fc $\gamma$ RIIIa glycosylation itself can also influence binding of $\mathrm{IgG}$, hinging primarily upon a single glycan at Asn $162(107,108,110,113)$. Indeed, there are vast donor-specific differences in monocyte derived $\mathrm{F} c \gamma \mathrm{R}$ glycoforms that could influence the effectiveness of antibody therapies as well as donor-derived cell therapies (110). A more complete understanding of glycosylation effects on ADCC, as well as innovative ways to generate uniform and specific antibody glycosylation targeted for donor phenotypes, is an area of active research.

\section{Experimental Setup for Imaging the IS}

Fluorescent light microscopy provides the unique advantage of being able to observe live cells, illuminating IS dynamics such as the spatial arrangement of receptors and ligands over time. Work in this area has been pioneered by the study of the $\mathrm{T}$ cell IS, which has been extensively reviewed elsewhere $(7,9,76,114-119)$. Study of the $\mathrm{T}$ cell IS has been in part driven by a more reductionist approach 

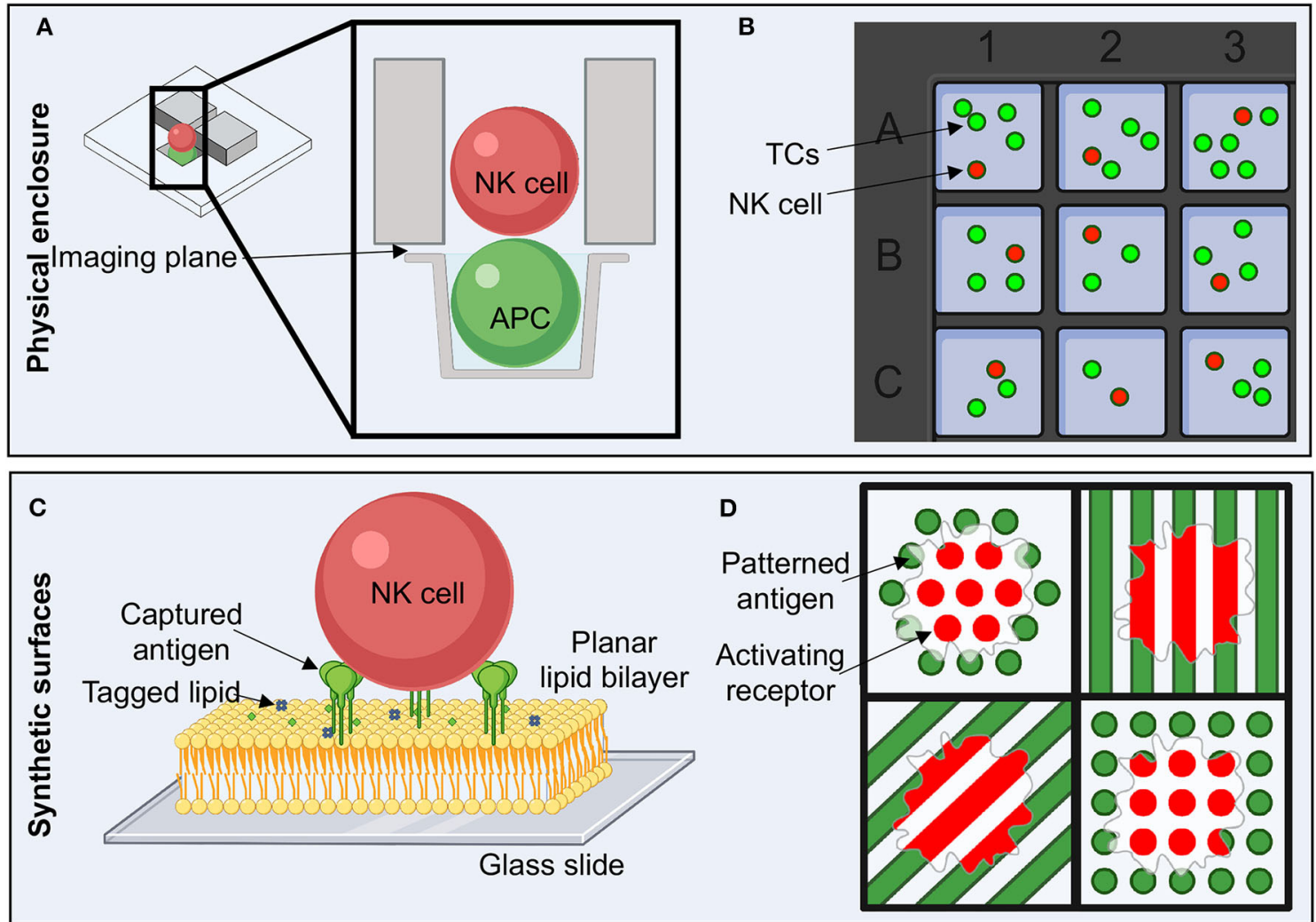

FIGURE 5 | Experimental setup to study NK cell activation and the immune synapse. (A) Flow cells with microwells allow the physical isolation of single cell pairs to image the immune synapse in the z plane or en face. (B) Microwell plates enable the isolation of a small number of TCs and NK cells in order to study live, non-adherent cells. (C) The use of planar lipid bilayers on glass slides is a reductionist approach to studying the NK cell immune synapse. Antigens can be attached to chemically modified lipids, enabling ease of titrating antigen density and type as well as lipid composition. (D) Activating ligands can be pattered in order to determine how spatial and geometric constraints affect many aspects of NK cell activation. TC, target cell.

to parse the very complex IS into more digestible pieces. These techniques have now been adapted to study the NKIS as well.

The first obstacle to overcome when addressing the question of the role of antibodies within the IS is how to set up and observe single cell interactions. This is especially critical in ADCC since antibodies will influence the earliest stages of IS formation, and therefore timing is crucial. There are several technologies that have been developed to address this issue, but they fall into two major categories: imaging live cells enclosed in a physical space and imaging live effector cells interacting with a synthetic surface representing a TC (114). I will briefly touch on a few examples here.

The first technique of imaging live cells requires physical isolation of these cells (Figures 5A,B). One approach for this has been the design of microfabricated wells, which are limited in diameter for single cells, but deep enough to allow a second cell to stack on top (120). This allows the imaging of the z-plane between the two cells where all the action of the IS takes place. Similarly, microfluidic chambers can trap pairs of cells and provide both face-on and side views of the IS (Figure 5A) (121). Both of these techniques have the advantage of high throughput but suffer from limits in imaging resolutions inherent to the microscopy techniques required for live cell imaging. Optical tweezers, which can capture an TC and present the IS to the focal plane of the microscope, also offer an intriguing solution for examining the NKIS in real time with improved resolution, however, without high throughput (122-124). This technique has been useful in predicting the effectiveness of chimeric antigen receptor (CAR)modified $\mathrm{T}$ cells and may have similar usefulness for CAR-NK cells (75).

Cells can also be trapped within microchambers, which limits the range that non-adherent cells can move (Figure 5B) (125). This allows the free movement of effector cells in real time and facilitates tracking of single cell movement. With the additional implementation of acoustic signals, cell to cell interaction is stimulated, which allows for increased observations (126-128). Here we are not looking directly at the IS, but rather looking at whole cell behaviors within the context of a more "real" environment. One can envisage the grafting of tissues into these chambers to observe NK cell infiltration or to add different antibodies into media within chambers to observe the effects on whole cell dynamics within the context of ADCC. 
A more reductionist approach to studying the NKIS utilizes synthetic forms of TC surfaces (Figures 5C,D). These systems are convenient for varying the type of antigen and also introducing spatial and geometric constraints. Supported lipid bilayers (SLBs) have gained traction in their utility to study the IS, as they allow for maintenance of the type of fluidity that would be encountered in cell membranes (Figure 5C) $(85,114,129-134)$. There are many different ways in which to assemble SLBs, which have historically also found high utility for studying the electrophysiology of ion channels, pumps and transporters (131, $135,136)$. For utility in biology, SLBs are typically formed by generating lipid micelles in solution and then depositing these onto ultra-clean glass slides $(85,137)$. Bilayers can integrate capture lipids, for example that contain nickel or streptavidin on their head groups, that can subsequently bind tagged antigens (Figure 5C) (137-139). In this scenario, antigen density can be titrated, or lipid composition can be easily adjusted.

Antigens or activating ligands can also be deposited directly onto substrate in predefined patterns using printing techniques (Figure 5D) (120, 140). This option allows for well-defined spatial constraints that can assist in probing how discrete patterns or geometries influence cellular activation and the organization of the IS, even within a single cell. For example, in an experiment where activating and inhibitory molecules are placed in distinct patterns, NK cell actin cytoskeletal rearrangement is more intense and patterned around activating signal patterns than inhibitory patterns (Figure 5D) (141). While this technique suffers from the static nature of the antigen presented, distances may be tightly controlled, and multiple different antigen-antibody complexes could potentially be examined simultaneously.

\section{Imaging the IS With Fluorescent Microscopy}

Fluorescent microscopy imaging techniques can provide a range of temporal and spatial resolution (117, 142-144). While some techniques allow dynamic temporal resolution, such as the tracking of events in real time, these often suffer from physical constraints that do not allow high spatial resolution. Wide-field fluorescence microscopy (WFM) gains back spatial resolution from deconvolution methods that allow sharpening of signal post-image acquisition (142). Laser scanning confocal microscopy (LSCM) is also quite often utilized due to ease, but loses temporal resolution due to slow scanning speeds, which impede looking at fast events like those happening in the IS (121). Here, spinning-disk confocal microscopy (SDCM) allows for quicker acquisition (10 to 100 -fold over LSCM) with lower photobleaching (117). Total internal fluorescence (TIRF) microscopy has limited $\mathrm{z}$-axis resolution but is quite useful for analyzing the IS, which occurs in a narrow plane $(145,146)$. Two-photon fluorescence microscopy (TPFM) can complement TIRF by allowing similar resolution but with the ability to look at subcellular properties $(117,147)$.

Conversely, spatial resolution shines in the realm of superresolution techniques $(76,85,89,115,142,148)$. This type of microscopy is not limited by the wavelength of light like the above examples. Stimulated emission depletion (STED) microscopy uses two lasers to activate and immediately deplete fluorophores, offering the ability to image smaller volumes $(115,149,150)$. STED can technically be used for live cell imaging but is still slower than SDCM and has limitations with fluorophores. Singlemolecule localization microscopy (SMLM) techniques (151), such as photoactivated localization microscopy (PALM) and stochastic optical reconstitution microscopy (STORM), utilize special photoactivatable probes that can indicate the single XYZ (more resolution in XY and less in $\mathrm{Z}$ ) location of molecules (152-154). SMLM techniques can be used on live cells but are more practical with higher resolution in fixed samples. More complicated equipment as well as image analysis algorithms have been developed to offer insight into $\mathrm{T}$ cell activation in 3D within living cells (148). Lattice light sheet fluorescence microscopy (LLSFM), for example, offers the next generation for studying live cell IS events, with much faster $\mathrm{Z}$ slice image acquisition than SDCM along with super resolution $(155,156)$. However, LLSFM will have increased utility once cost and complexity both go down.

\section{Future Techniques for Understanding the IS}

The future of imaging and understanding the NKIS will rely upon two major factors. One will be the marrying of high-resolution techniques, offered by electron microscopy for example, with those of resolution limited techniques, such as light microscopy. The other will be making new technologies more widely available to biologists, which is only a matter of time $(157,158)$. Such a renaissance has been seen in the field of electron microscopy with the advent of user-friendly microscopes and data analysis software (159). As far as the former, I will highlight a few exciting developments to keep an eye on in the coming years.

In the realm of electron microscopy, the aspirational goal is to achieve sub-nanometer resolution of proteins and complex macromolecular systems in situ. Since most high-resolution techniques rely upon averaging, this is not readily possible, but more advanced techniques in cryo-electron tomography (cryo-ET) are quickly closing this gap (160-162). Phase plates, ideal for tomographic techniques to increase image contrast, have been instrumental in solving complex macromolecular assemblies within cells. Additionally, focused-ion beam (FIB) milling instrumentation allows for exquisitely thin and detailed cell sections to be isolated (Figure 6A) (163, 164). CryoET examples include cytosolic and mitochondrial structures of actively translating ribosomes (165), complex actin and microtubule network assembly $(166,167)$, and intriguing views of the neural synapse (168). To examine the nuclear pore complex, detergent solubilization and removal of nucleic acids has enabled thinning samples as much as possible while maintaining 3D structure. Combined with integrative structural biology techniques, we now have the most detailed views of the intact nuclear pore complex ever seen (169). Cryo-ET, however, is labor intensive and requires a high level of expertise that has not become as streamline as single particle analysis. However, 

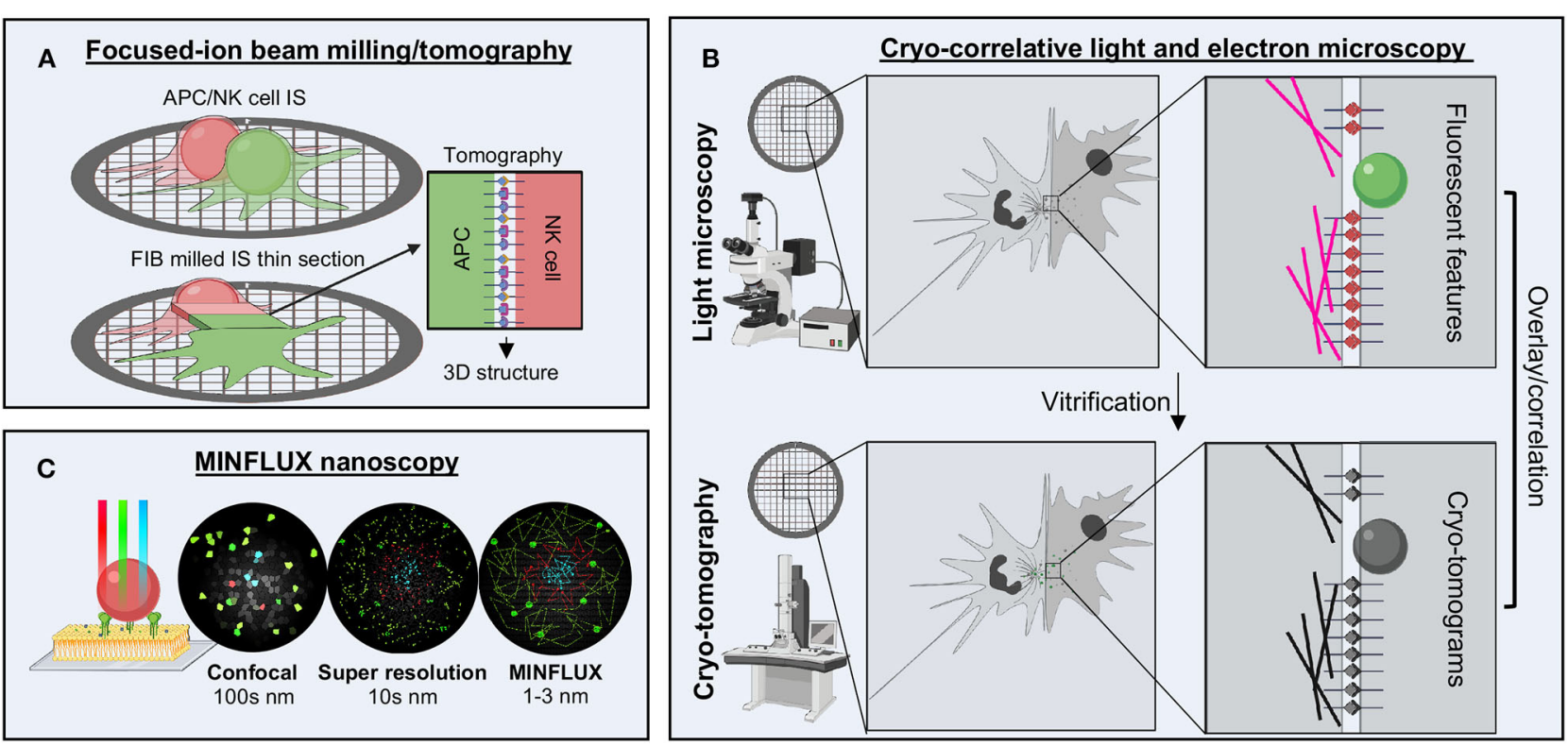

FIGURE 6 | Future techniques for studying the NKIS. (A) FIB milling combined with tomography enables the generation of a thin layer to image the molecules bridged between cells. (B) Cryo-CLEM enables the localization of several structures within the immune synapse by super resolution microscopy followed by higher resolution structural analysis by tomography, which can be overlaid to provide additional details not offered by either technique alone. (C) MINFLUX nanoscopy offers the highest spatio-temporal resolution available of any light microscopy techniques, going beyond the limits of confocal and super resolution, down to the range of $1-3 \mathrm{~nm}$. FIB, focused-ion beam; nm, nanometer.

the field is rapidly moving toward automation and increased sophistication in data analysis of cryo-ET data. This field holds great promise as a tool for examining cell to cell contacts, such as the NKIS (Figure 6A).

Cryo-correlative light and electron microscopy, or cryoCLEM, attempts to fill the gap between light and electron microscopy (Figure 6B) $(170,171)$. In this technique, whole cells are first imaged using fluorescent microscopy techniques to localize and identify features of interest. Next, cells are vitrified and imaged using cryo-ET, allowing for identification of features and subcellular location of the somewhat higherresolution electron density maps generated. Genetically encoded fluorescent proteins allow the maintenance of cellular integrity and examination of fluorescence post-vitrification, or samples can be fixed, permeabilized and stained prior to freezing. Super resolution techniques are also starting to be combined to provide even more details (172-174). Cryo-CLEM may be a way to more accurately identify the location of signaling proteins within the IS and then extend results to the high-resolution context through electron microscopy.

Within the realm of light microscopy, a new technique has recently broken all the previous barriers associated with resolution limits, including spatial and temporal limitations as well as photobleaching effects. Known as MINFLUX, this revolutionary technique combines the super resolution techniques of PALM/STORM with those of STED by establishing the coordinates of proteins through minimal emission fluxes (Figure 6C) (175-177). This allows for nanoscale precision on the order of $1-3 \mathrm{~nm}$ spatial resolution. Moreover, this technique is adaptable to both scanning and standing-wave microscopes and can be used on fixed or live samples as well as in 3D. Tracking of single molecules within live Escherichia coli cells over long distances as well as highly detailed, multicolor labeling of the nuclear pore complex have been the earliest examples $(175,177)$. Clearly, this technique could be adaptable to tracking multiple different receptors within the NKIS. The only drawback at this current point is expense and availability.

\section{GEOMETRIC AND SPATIAL CONSIDERATIONS WITHIN THE NKIS}

IgGs are highly abundant within the human body at any given time, on the order of 7.5-22 mg/mL. Therefore, for ADCC to be an effective strategy for targeting cellular insults, NK cells must distinguish between free and specifically bound antibodies. This is thought to be achieved by the aggregation and agglutination that antibodies undergo upon antigen binding, whether to cell surface exposed antigens or soluble (178). This brings Fc domains in close proximity, allowing the clustering of cellular receptors. However, this explanation does not account for the sophisticated arrangements that signaling receptors must adopt in order to propagate a real signal, nor does it explain the reason and mechanisms associated with the variety of antibodies, receptors and glycoforms that exist. There is evidence to suggest that antibody arrangement is crucial for effector functions to proceed, that geometry and spacing can tune responses and that antibody allostery may also assist in regulating cellular activation. Below, 
I will discuss more detailed current knowledge of the early stages of antibody-based signaling and activation and provide examples that point to the concerted molecular underpinnings of effector functions.

\section{Initial Stages of ADCC}

Once an NK cell has docked with a potential target, if opsonized antibodies are present, then Fc $\gamma$ RIIIa will subsequently bind to those IgGs. Alone, the binding affinity of Fc $\gamma$ RIIIa for IgG is estimated to be in the high nanomolar range (at least in vitro) but also depends on the genotype of individuals (31). For activation to proceed, however, the affinity between Fc $\gamma$ RIIIa and IgG must be strong enough to allow for sustained interaction. IgG affinity is provided by the aggregation of IgG on immune complexes, increasing antibody avidity. Antibody aggregation is necessary because Fc $\gamma$ RIIIa must adapt to a molecular arrangement that allows intracellular phosphorylation of cytoplasmic domains. Such an arrangement provides a platform for kinase binding and activity that is absent in monomeric Fc $\gamma$ RIIIa. It stands to reason that there must be discreet forms of Fc $\gamma$ RIIIa activation complexes beyond what simple aggregation implies. Indeed, there is evidence to suggest that such a form could be dimeric, as we will discuss more in the next section.

Once antibodies have successfully bound to the $\alpha$ subunit of Fc $\gamma$ RIIIa through the ectodomain, this signal must be propagated to the intracellular side of the NK cell. This is achieved by costimulatory signal adapter molecules, which for Fc $\gamma$ RIIIa is either FceRI g or CD3 $\zeta$ (CD247) (Figure 1B) $(13,69,70)$. These adapters were first attributed to the $\operatorname{FcR}$ for $\operatorname{IgE}(179,180)$ and the TCR complex $(181,182)$, respectively, but are also adaptable to Fc $\gamma$ RIIIa for ADCC. The $\gamma$ or $\zeta$ adapters exist as a single pass transmembrane protein that forms a dimer through a cysteine bond (183-185). There appears to be no preference for either as they are found equally associated with Fc $\gamma$ RIIIa (184). Together, the adapter homodimer and Fc $\gamma$ RIIIa monomer are thought to form a non-covalent three-helix bundle (184). Mutations that dissociate adapter molecules from Fc $\gamma$ RIIIa have been shown to prevent cell surface trafficking and are also thought to prevent Fc $\gamma$ RIIIa degradation $(184,186)$.

\section{ADCC Signaling}

Although the overall structural motif of the macromolecular signaling complex has yet to be elucidated, once Fc $\gamma$ RIIIa selfassociates, downstream signaling can then proceed. The $\gamma$ or $\zeta$ activating adapter molecules contain cytoplasmic tails with ITAMs (187). In the proper conformation, these ITAMs can be phosphorylated at two of 6-8 tyrosine sites, setting up a docking site for Src-family kinases. It may be possible that Src kinases dock and rely on a specific dimeric motif of associated Fc $\gamma$ RIIIa and adapters for the kinases to dimerize themselves and auto phosphorylate, structurally similar to what has been shown for the JAK2 kinases (188). Indeed, Src dimerization is predicted to be necessary as its role as a hub for multiple signaling activities (189-191).

Once phosphorylated, the signaling adapters are ready for recognition by Syk or Zap70, for example, through tandem
SH2 domains (192-194). Syk or Zap70 interaction with phosphorylated ITAM domains leads to the downstream activation of several signaling pathways. Concurrently, Fc $\gamma$ RIIIa cross-linking activates PLC-gamma enzymes to generate inositol 1,4,5-trisphosphate (IP3) and sn-1,2-diacylglycerol (DAG), leading to $\mathrm{Ca}^{2+}$ release from stores within NK cells, which is required for granule release. Fc $\gamma$ RIIIa cross-linking also activates PI-3 kinase, which produces additional signaling molecules to assist in ADCC-associated activation activities. Additional associated signaling pathways include the Ras, ERK2, MAPK, Vav/Rac, and NFAT pathways. Each of these pathways leads to activities such as actin reorganization, cellular proliferation and cytotoxicity. Further, the JAK/STAT pathway can also be secondarily activated, leading to upregulation of cytokines and chemokines, recruiting other cells or enhancing effector functions (195).

Signaling is a highly complex and multicomponent process that can change depending on extracellular stimuli. For example, antibody activation via FcyRIIIa sets up ADCC with a particular response, but that response differs from direct cytotoxicity or activation inhibition $(78,196)$. Increased understanding of the complex signals that occur during NK cell activation will help us to understand how to modulate ADCC activity, perhaps through new designs of antibodies or a synergistic combination of antibody and small molecule.

\section{Receptor Movement and Lipid Composition}

The initial stages of ADCC as well as the formation of the NKIS are both intrinsically linked to composition of the cell plasma membrane. Here is where membrane bound receptors interact both extra- and intracellularly to generate a robust reaction on the cellular level. Once thought to be a somewhat homogeneous environment, the cellular membrane is actually a circus of different elements, composed of a wide range of lipids that tightly control many cellular activities, including immune signaling. While the evidence for how lipid composition of cells is organized and influences cellular activities is not wholly realized, due to the difficulties associated with studying lipid composition in situ, there is still some compelling data that warrants discussion, especially in relation to immune signaling and ADCC.

The composition of eukaryotic plasma membranes is primarily of glycerophospholipids, with head groups attached to at least one unsaturated acyl chain $(197,198)$. While these lipids are sufficient to form a bilayer, it is known that sterols and sphingolipids also make up a large portion of the plasma membrane. The sphingolipids can be further classified into ceramide-based sphingomyelin or carbohydratebased glycosphingolipids, both which are often saturated in their acyl chains. Of the sterols, cholesterol is the principle component. Both of these additional lipids are of much lower abundance in internal membranes but are made in the ER and Golgi and transferred to the cell surface. The composition of the inner and outer leaflets of the plasma membrane is also known 
to be different, with cholesterols and sphingolipids thought to preferentially reside in the outer leaflet.

More than any other component, cholesterol changes the properties of the bilayer by increasing rigidity and reducing permeability, while still allowing free-lateral movement of proteins and lipids. Model lipid studies indicate that cholesterols and sphingolipids form distinct domains within the more fluid background of the plasma membrane, often referred to as lipid rafts, and that transmembrane proteins can be included or excluded from these domains based on their own physical properties (199-202). Within the outer leaflet, GPI-anchored proteins are enriched (203). These are subsequently linked to the inner leaflet by signaling proteins that are preferentially found in this portion of the plasma membrane, forming signaling platforms.

Evidence for such signaling platforms, especially in regard to Fc $\gamma$ RIIIa as well as its associated signaling domains, is compelling in NK cells $(90,204-208)$. Immunoregulatory elements can be preferentially partitioned within different lipid environments, with positive signaling components such as the Src and Lck family kinases being found in cholesterol rich lipid rafts, while negative regulators such as phosphatases are excluded from these regions. By clustering these elements within microdomains, signaling can be more easily and readily achieved. Although NK cell ADCC is not associated with GPI-anchored proteins, many activating immune receptors are indeed GPI-anchored, which also suggests that immune signaling is biased toward lipid rafts.
Evidence suggests that negative regulation of NK cell cytotoxicity results from blocking the association of activating receptors within lipid rafts (Figure 7A) (204, 205, 207). It is thought that actin cytoskeletal rearrangement assists in the association of lipid rafts containing positive regulatory components within the immune synapse (208). If negative regulatory components dominate the signaling platform, then actin rearrangements can be blocked, thus limiting the rearrangements of downstream signaling components to lipid rafts containing primarily positive signaling elements. This may explain why actin cytoskeletal rearrangement is one of the earliest and fastest physiological responses to NK cell activation.

Lipid rafts likely alter the way in which signaling components interact once liganded to a target cell. When considering the many ways in which an antibody bound to its target antigen could be presented to Fc $\gamma$ RIIIa, it is important to consider how such geometric and physical constraints may be affected by the more rigid confines of a lipid rafts. Indeed, cholesterol enrichment seems to be a harbinger for more efficient NK cell cytotoxicity (209), but there is no evidence to address how this affects ADCC or how the physical arrangement of antibodies within a macromolecular signaling complex may influence activation. Conversely, the lipid environment of a target cell could also affect how antibodybound antigens are presented within the IS (Figure 7B) (210). Much less attention has been paid to the target cell side of NK cell cytotoxicity; however, some evidence suggests that lipid composition is vital to the sensitivity of target cells to attack
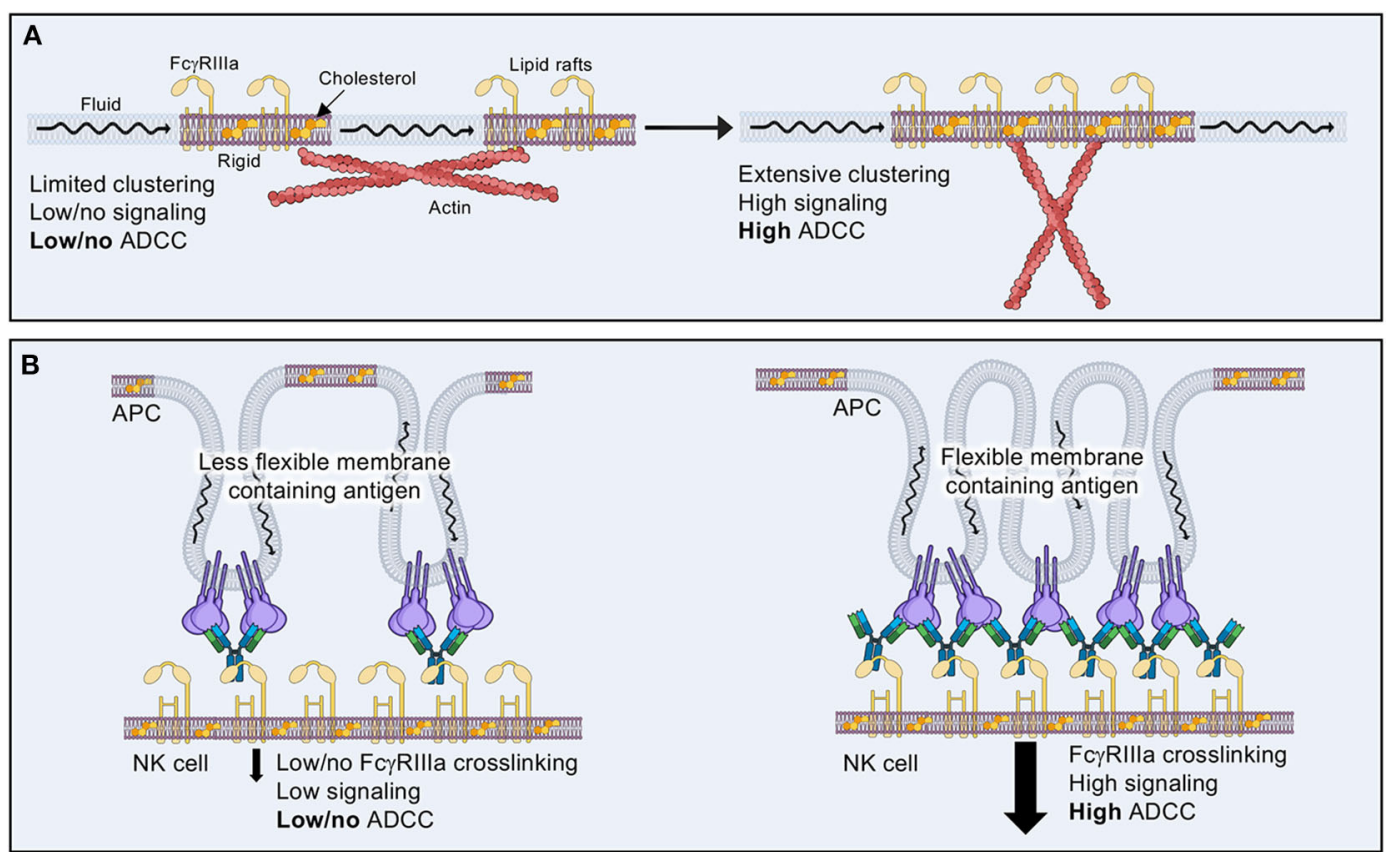

FIGURE 7 | The effects of lipid composition on ADCC. (A) Lipid rafts containing activating receptors and higher levels of cholesterol tend to be more rigid and isolated in the plasma membrane of resting or inactive NK cells. Actin cytoskeletal rearrangements are thought to aid in bringing lipid rafts together in order to allow tighter clustering of signaling molecules and increased cytolytic activity. (B) Target cell membrane lipid composition may aid or inhibit NK cell ADCC by how well antibody coated antigen is able to cluster, thus promoting Fc $\gamma$ RIlla receptor clustering. 
(210). There is much room for exploration in the realm of lipid composition and its influence on ADCC, which may in turn have important implications for the choice of antibody used for immunotherapeutic purposes.

\section{Spatial and Geometric Constraints Within the IS}

For NK cell signaling to occur, extracellular signals must be propagated across the cellular membrane. This necessitates some type of unique arrangement of proteins that differentiates a resting cell from a cell that is detecting something in the extracellular environment. In the case of ADCC, this starts with understanding the arrangement of Fc $\gamma$ RIIIa. Is there a singular structural motif that must be achieved in order for activation to occur? Or is the arrangement of these receptors more stochastic and tunable to the subtleties defined by extracellular factors? Like most realities of biology, the answer likely lies somewhere in the middle.

In an analogous system, the $\mathrm{T}$ cell immune synapse, much work has already been done to answer these questions, ultimately setting a paradigm for lymphocyte-based signaling (181, 183, 185, 211-215). Similar to Fc $\gamma$ RIIIa, the T cell receptor (TCR) is composed of extracellular domains that recognize peptide bound MHC-I. These domains, a heterodimer of $\alpha$ and $\beta$ domains, are single pass transmembrane proteins that must also pair with adapters to propagate signal. Nucleation is accomplished with the $\mathrm{CD} 3$ hexamer, comprised of heterodimers of $\mathrm{CD} 3$ $\gamma \varepsilon$ and $\mathrm{CD} 3 \delta \varepsilon$ as well as $\mathrm{CD} 3 \zeta \zeta$, which is one of the same adapters used by Fc $\gamma$ RIIIa. The resultant supramolecular complex is thought to be the basal unit for signaling and requires very tight spatial interaction, which was recently resolved by cryo-EM, revealing a crisscrossing network of transmembrane subunits (185). Ligand binding does not induce any obvious structural changes, with the caveat that this structure utilized glutaraldehyde fixation. There are some single molecule data as well and NMR studies that suggest that reorganization within the TCR signaling complex may occur upon ligand binding still $(216,217)$. Previous structural data also suggested that a complete signaling complex in solution may be dimeric (211). It is thought that the antigen-bound TCR then interacts with actin and other signals to function as a mechanosensory unit $(123,218)$.

Studying microcluster formation and dynamics of signaling kinases that are anchored to the plasma membrane has been critical to our understanding of TCR signaling and provides many lessons for studying the NKIS. Studies using PALM revealed that in cells activated on glass coverslips, associated signaling molecules like LAT and SLP-76, which links to actin filaments, form in much smaller nanoscale sized clusters than previously postulated $(146,219,220)$. The increased spatial resolution of PALM also revealed that signaling could occur in nanoclusters that may only contain signaling units as small as dimers of the TCR as the minimum requirement for signaling (221-224). Complementary studies using light sheet STORM of activated $\mathrm{T}$ cells from mice showed similar types of spatial organization occurs in vivo (225).

On the antigen side of immune activation, antigen presentation and spacing seems to be critical for thresholding $\mathrm{T}$ cell activation. Several studies using nanoscale spacing of activating molecules suggest that differential activation can be achieved depending on the space provided within the IS $(114,212,226,227)$. One study integrating both lateral and axial spacing of antigen determined that tight $2 \mathrm{D}$ clusters with limited axial spacing of $<50 \mathrm{~nm}$ was an ideal arrangement for T cell activation (212). Such spacing is thought to fortify clustering based activation while excluding CD45, which must exit the IS in order for activation to proceed. Another study concluded individual activated TCRs may contribute more to $\mathrm{T}$ cell activation than overall clustering (223). This adds some clout to the idea that there is a necessary arrangement of the TCR that qualifies activation, potentially a dimer as previously suggested.

For ADCC-based activation in NK cells, there is evidence to support a signaling complex may involve Fc $\gamma$ RIIIa dimers, which have greater appreciable binding to $\operatorname{IgGs}(14,70,184,228)$. Dimers are quite prevalent throughout signaling biology and are thought to generate universal platforms for kinases with broad activity (Figure 8A) (181, 191, 213, 229-232). Cytokine mediated signaling provides the richest examples of dimer mediated signaling, with a large diversity of structures induced by cytokine binding $(229,230,233)$. There are many additional examples of homo- and heterodimeric complexes that drive signaling, including growth factor receptors, insulin and other hormone signaling receptors and nuclear receptors (Figure 8A). In each of these cases, dimerization may occur in several different stoichiometries and can orient dimers in a plethora of ways. Further, toll-like receptors also require extracellular antigen-based dimerization for signaling to occur (Figure 8A) (234). Given the diversity of dimerization in signaling, it seems highly likely that ADCC signaling may follow a similar type of organization.

The idea of signaling dimers in ADCC has been previously postulated. Artificial dimers of Fc $\gamma$ RIIIa were sufficient to reproduce NK cell activity and conversely increase affinity for IgG (228). Additionally, ectodomains of Fc $\gamma$ RIIa within a crystal lattice suggest a possible domain arrangement that may extend to other Fc $\gamma$ Rs. Mutation of critical residues in this dimeric interface demonstrated reduced cellular activation but not ligand binding (235). Later structures of Fc $\gamma$ RIIa demonstrated a new dimer interface potentially that serves as an activating arrangement of signaling as it could reasonably accommodate two opposing Fc domains as well as ligand bound Fabs (Figure 8B) (236). The authors proposed a model where constitutive dimers exist on the cell surface in an inactive arrangement that changes upon ligand binding, posing the intracellular signaling domains in an active formation. Perhaps this is similar to the "rotation model" of other signaling motifs, where less flexible intracellular domains are opened up for phosphorylation upon extracellular ligand binding (Figure 8C) (233). Fc $\gamma$ RIIa, unlike the other Fc $\gamma$ Rs, does not require adapters for signaling, having its own cytoplasmic ITAMs. It is not clear if 

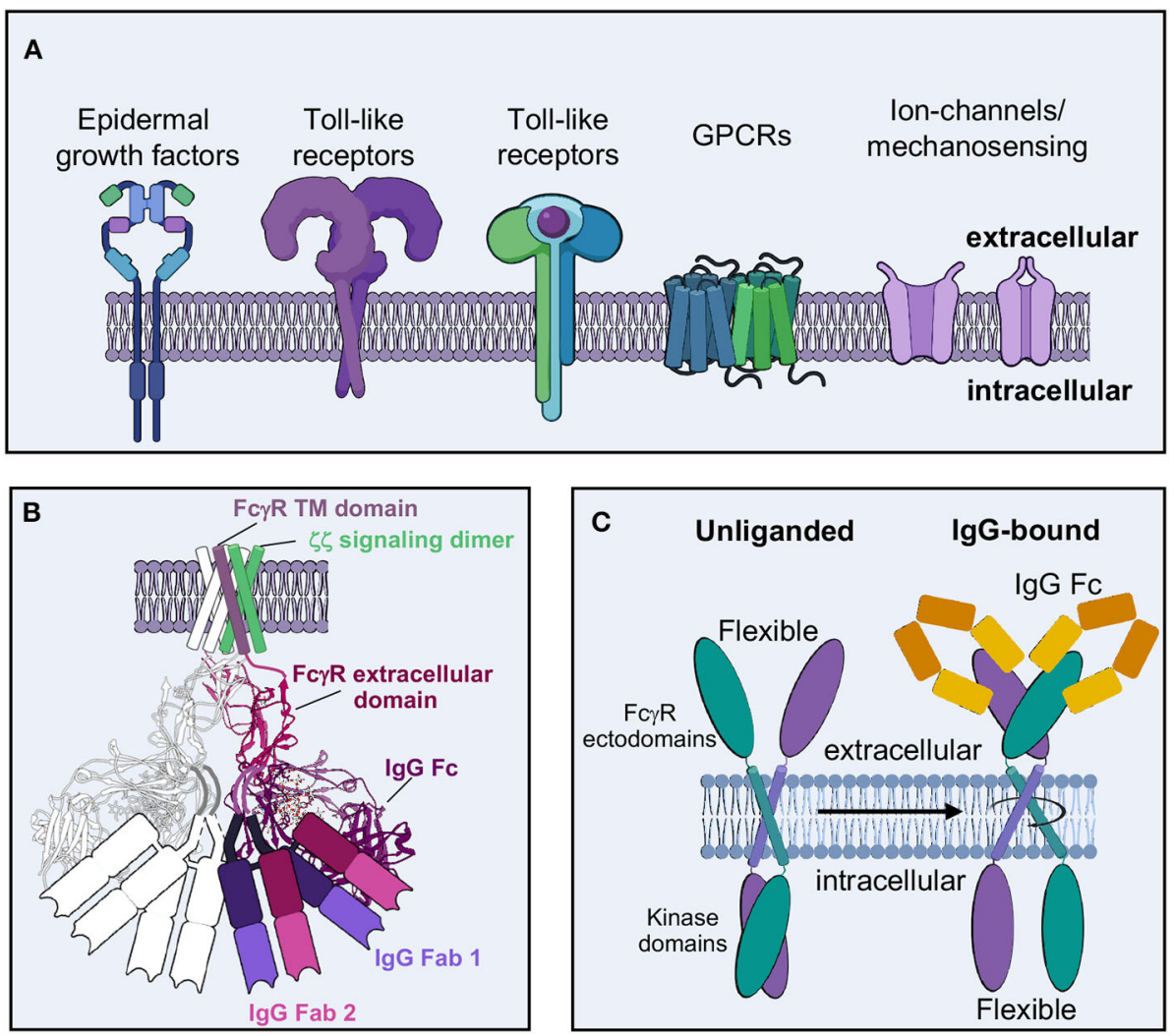

FIGURE 8 | Molecular basis of effector cell activation. (A) Dimers are prevalent molecular motifs in cellular activation throughout the immune system. (B) Potential dimer model of IgG-Fc $\gamma$ R-CD3 $\zeta \zeta$ activation complex, based off structures of complex components [Fc $\gamma R$ Rllb-Fc from PDB-3RY6 overlaid on Fc $\gamma$ RIllb crystal contact dimers from PDB-3RY5; model of transmembrane assembly of CD3 $\zeta \zeta$ structure from PDB-2HAC and model of Fc $\gamma$ RIIla/adapter assembly from Blazquez-Moreno et al. (184)]. (C) Potential model of downstream antibody-mediated signaling based on the "rotation model," which postulates that intracellular kinase domains are exposed for phosphorylation upon proper dimer assembly when extracellular activating ligands bind.

Fc $\gamma$ RIIIa or other Fc $\gamma$ Rs exist as a similar constitutive dimer on the cell surface. Achieving a similar dimeric arrangement of other Fc $\gamma$ Rs ectodomains may be a critical component for successful ADCC and additional effector activities, as I will discuss in more detail below.

There is evidence for other types of dimeric signaling motifs that suggests that the immune response is not "on or off" in these structural motifs but rather may be tunable. For example, the cytokine Erythropoietin (EPO) and its associated receptor EpoR can be changed in their association topology by diabodies that re-orient their geometry and lead to differences in intracellular signaling (230). Other examples, such as tumor necrosis factor (TNF) signaling as well as some prokaryotic chemoreceptors such as Tar, further demonstrate that dimer formation alone is not always sufficient for signaling and that conformational changes may be additionally necessary $(68,232)$. Throughout all these examples, there seem to be thresholds and variations in geometries that lead to the idea that cellular activation can be tuned in almost any type of signaling event, possibly even NK cell ADCC.

\section{Complement Dependent Cytotoxicity and Comparison to ADCC}

Complement is thought to be a more ancient form of immunity (237); therefore, principles of complement, especially for IgGs, may have important implications for ADCC as well. Complement is another function of the modular antibody that leads to target cell death without the need for effector cell activity. In complement, antibodies binding to cell surface antigen set the stage for additional complement associated proteins to assemble an activation platform ultimately leading to complement deposition and effector cell phagocytosis or assembly of the membrane attack complex (MAC) (238). A plethora of studies have previously set the molecular requirements for complement assembly, along with many isolated structures of complement related proteins, but it was tomography that really started to reconcile these observations (239-241).

Revisiting a fortuitous observation of the first full length structure of a human antibody (242), Diebolder and colleagues tried to understand possible functional consequences of $\mathrm{Fc}$ interactions seen in crystal packing, seeding hexameric arrays 

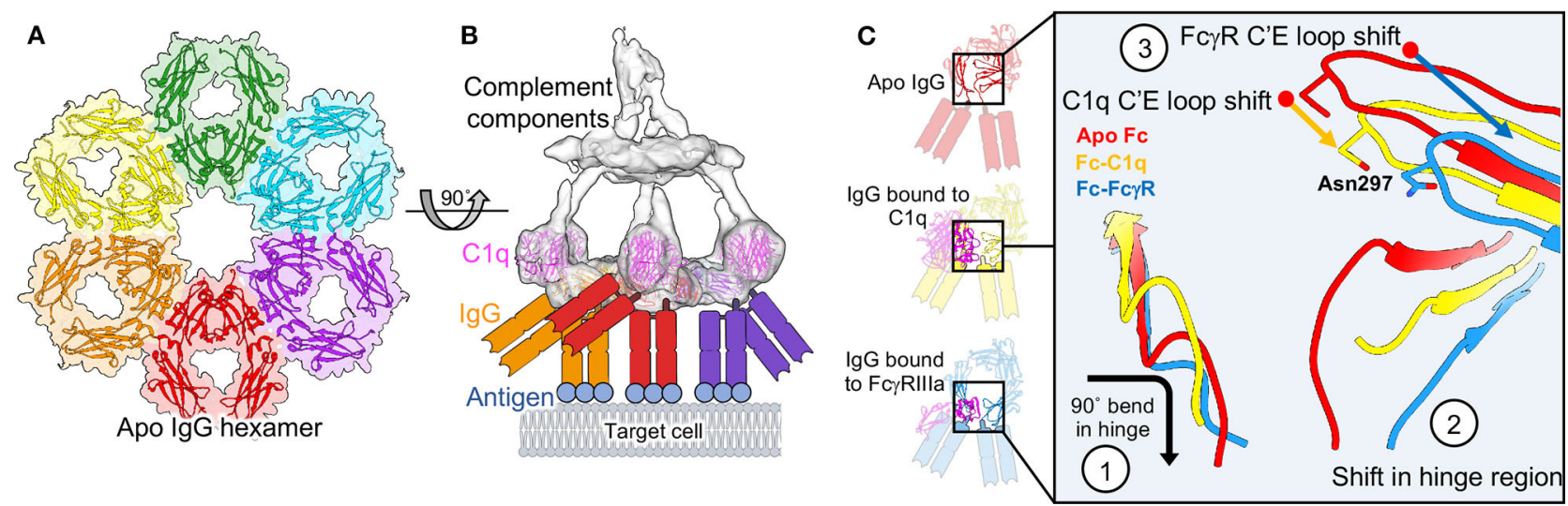

FIGURE 9 | Molecular basis of complement and comparison to ADCC. (A) Fc hexamers form the basis for complement deposition (PDB-1HZH). (B) Tomography of complement deposition indicates that IgG FC domains bend parallel to the antigen presenting cell, presenting the binding domain for C1q (EMD-4232, PDB-6FCZ). (C) Both $\mathrm{C} 1 \mathrm{q}$ and $\mathrm{Fc} \gamma \mathrm{R}$ binding induce similar conformational changes in the $\mathrm{FC}_{\mathrm{C}}$ domain compared to apo-Fc including (1) a 90 degree bend in the hinge-region loops, (2) a shift in the position of the hinge-region loops and a widening of the base of the Fc and (3) a shift in the position of the C'E loop, including the position of Asn 297 and the associated glycan (Apo Fc from PDB-1HZH, Fc-C1q from PDB-6FCZ and Fc-Fc $\gamma$ R/Fc $\gamma$ RIIla from PDB-3WN5).

(Figure 9A) (239). These hexamers were reminiscent of evidence indicating that IgG would need to form these types of structures in order for the complement cascade to proceed (243). Mutations that limited Fc-Fc interaction lead to decreases in complement activity while supporting mutations increased activity. Tomographic structures of assembled IgG on antigen presenting liposomes displayed the same type of hexamers seen in crystal packing (Figure 9B). Further, it was observed that $\mathrm{Fc}$ domains bend into a plane parallel with the antigen presenting plane, presenting the epitope for the first complement protein $\mathrm{C1q}$, which was also observed in their structures when assemblies were made in the presence of complement proteins (Figures 9B, C). Interestingly, only a single Fab of IgG was necessary for complement deposition, freeing up the rest of the IgG structure to assemble properly (Figure 9B). Bispecific antibodies actually performed better in complement assays.

Later EM observations of pentameric and hexameric IgM also showed very similar structural assembly for complement, with many additional proteins and observations added on $(240,241)$. In these observations, both Fab arms of the IgM were bound to antigen, which suggests that either IgM and IgG antigen recognition geometries are different, or there is a dependence on antigen type. Previous studies on IgM alone indicated that these antibodies exist in a pre-bent shape that may help to influence complement binding, whereas IgGs tend to be much more flexible in solution (244-246). More recent high-resolution cryoEM structures of IgM as well as IgA are beginning to give us even more detailed insight into how full-length antibodies operate preand post-receptor binding, hopefully providing lessons that can extend to other immunoglobulins $(22,247)$.

A recent structure of Rituxumab Fab bound to CD20 indicated that the antibody recognizes CD20 dimers and that Fab-Fab interactions are important to antibody binding (248). The authors presented some evidence that these types of Fab-Fab interactions may promote hexameric assemblies important for complement deposition. Fab-Fab and/or Fc-Fc interactions may be a much more prevalent antibody adaptation as there are more examples in the literature, such as the Fab-Fab interactions for some malaria antibodies (249).

Most intriguing is the folded presentation of Fc in both IgG and IgM complement assemblies, that is similar to those seen in Fc-Fc $\gamma$ R structures (Figure 9C) $(42,239)$. Although Fc $\gamma$ Rs can bind free IgG, perhaps a folded Fc domain is required for proper Fc $\gamma \mathrm{R}$ dimer assembly and signaling. Varying degrees of Fc presentation based on antibody binding angle or the number antigens engaged by an IgG simultaneously may modulate Fc $\gamma \mathrm{R}$ dimerization, thus tuning the immune response and leading to the differential innate activities observed by antibodies with identical phenotypes but varying levels of ADCC.

\section{Antibody Allostery}

The idea of antibody allostery or "intramolecular signaling" has been discussed for many decades and remains a debated topic in the antibody field (Figure 10) (250-253). This hypothesis proports that the Fab and Fc domains of an antibody communicate through structural properties inherent to antibodies. To that end, antigen binding in the variable domains would change structural conformations of constant regions, priming them for ideal FcR binding that would be lacking in the apo form of the antibody. However, the reigning theory behind antibody structure-function relationships is that Fab and Fc operate independently of each other, with the former binding to antigen and the later binding to FcRs without one affecting the other directly (178). Antigen-induced aggregation of IgG is thought to increase the relatively low affinity of receptor binding affinity through avidity and induce receptor aggregation that is required for downstream signaling. Without antigen, the 1:1 interaction of $\operatorname{IgG}$ and $\mathrm{Fc} \gamma \mathrm{R}$ remains weak and/or does not induce receptor clustering even in high affinity interactions like Fc $\gamma$ RI. While there is an ample amount of evidence to support 

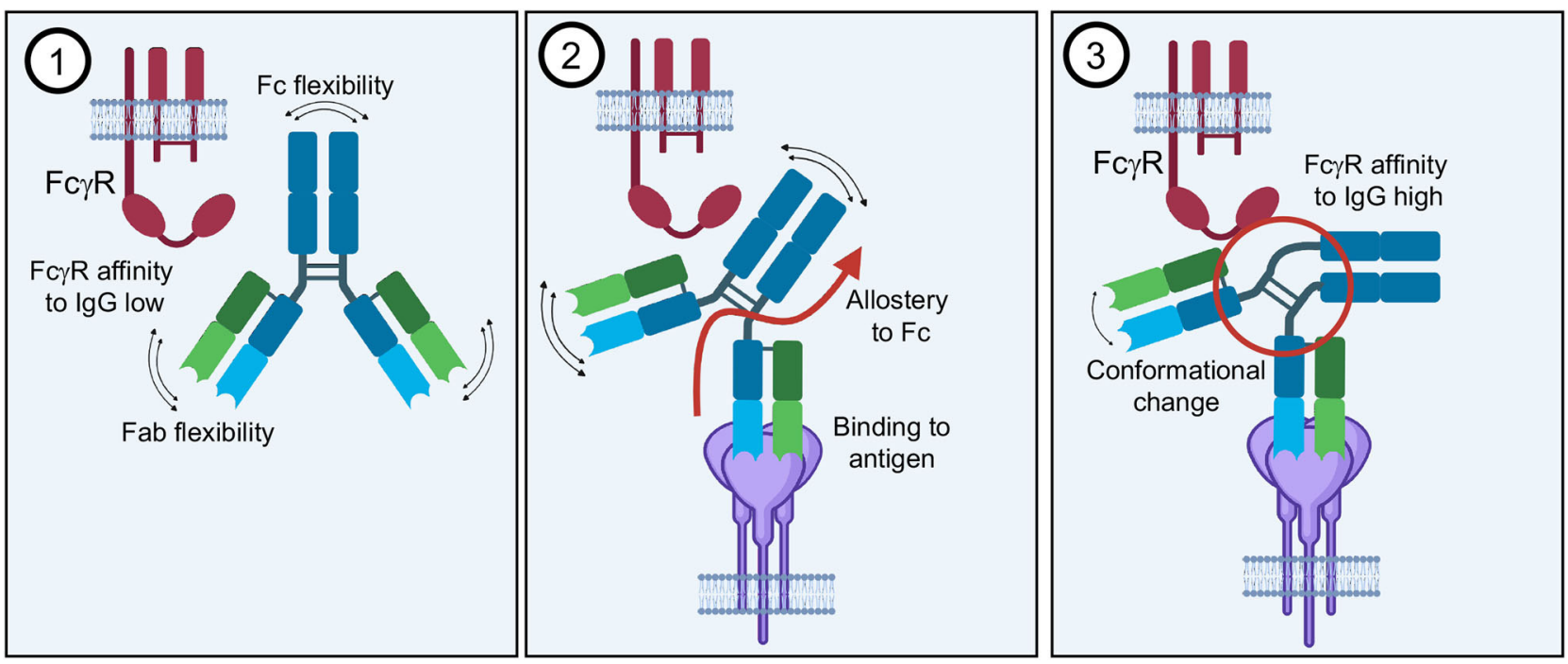

FIGURE 10 | Antibody allostery. The theory of antibody allostery or "intramolecular signaling" asserts that (1) an apo-lgG has flexibility that impedes its affinity to Fc $\gamma$ Rs. (2) Antigen binding generates an allosteric signal from the Fab to Fc domain. (3) Allostery causes a conformational change in the Fc as well as decreased flexibility that facilitates Fc $\gamma R$ binding with higher affinity.

this type of associative cooperativity, there continue to be models and complementary evidence that antibody allostery may play a subtle but significant role in Fc-mediated effector functions.

Studies of antibodies in solution demonstrate that there is a large degree of flexibility associated with the antibody structure, mostly likely imparting a wider sampling space for a diversity of target antigens (Figure 10) (244, 245). Furthermore, crystal structures of intact IgGs also indicate that the hinge-regions are largely responsible for this flexibility, although these regions tend to be poorly resolved and in the confines of a crystal lattice (68). However, detailed dynamics studies of antibody behavior in solution provide computational evidence that antigen binding changes the sampling space of Fc as well as the flexibility, providing a type of "rigidity" that is not found in unbound antibodies, which may lead to greater $\mathrm{Fc} \gamma \mathrm{R}$ affinity in the presence of antigen (254).

There is some direct evidence to suggest that Fab binding also has consequences for the constant region of an antibody, at least within in the Fab domain. Comparison of several crystal structures of native and liganded Fab demonstrate changes that occur within the Fab hinge as well as elsewhere in structures (255). Although earlier studies comparing bound and unbound Fab run contrary to these observations, it appears that there are some antigen/antibody specific properties that may account for variability. This may also point to an explanation for differing innate properties of antibodies depending on the epitope.

Moving toward the Fc end of the antibody, there are several studies that indicate that perturbations to the Fc region can affect binding to antigen, for example with Pertuzumab (as an IgA1 and IgA2) and Her2 binding (256). Similarly, many other studies have shown that using identical variable regions with different constant regions (i.e., isotype or subclass switching) leads to variable antigen binding as well (257). Further, an antibody's ability to neutralize viruses is possibly linked to its ability to bind to $\mathrm{Fc} \gamma \mathrm{R}$ and perform effector functions (258). Although indirectly, the above evidence suggests that Fc and Fab are intrinsically linked.

Looking back to complement, we now know that antigen binding is indeed required for the formation of $\operatorname{IgG}$ hexamers, leading to a bending of Fc and Fc-Fc interactions (239). Since these hexamers do not form stochastically in solution, and since membrane bound antigens likely do not stochastically form the hexameric shape required for complement deposition, a system of allostery seems a likely explanation for how antigen binding leads to complement associated macromolecular assembly (259). Higher resolution studies of the complement activation complex, perhaps using single particle studies, may be required to confirm this and to piece together what intermediate IgGs look like moving into the complement-bound state $(259,260)$.

Detailed structures of full IgGs alone will also provide critical data showing the structure of $\mathrm{Fc}$ in solution when not influenced by neighbors within a crystal lattice. Indeed, comparing structures of free $\mathrm{Fc}$ and $\mathrm{Fc}$ bound to $\mathrm{Fc} \gamma \mathrm{R}$ show that $\mathrm{Fc} \gamma \mathrm{R}$ binding induces a change in $\mathrm{Fc}$ from symmetric to asymmetric, which precludes a second $\mathrm{Fc} \gamma \mathrm{R}$ from binding (Figures 1D, 9C) (12). It would be most intriguing to determine if antigen binding pushes Fc toward a more asymmetric shape, perhaps facilitating $\mathrm{Fc} \gamma \mathrm{R}$ binding. The increasing capacity of cryo-EM to solve structures of very small, Fc-sized molecules as well as to deal with the type of sample heterogeneity associated with IgGs will prove to be a valuable tool toward these efforts.

Together, these data collectively fit into a model of leukocyte variability in relation to effector functions and suggest a mechanism that inherently must include allostery. This is not to suggest that antigen induced aggregation is not necessary, but 
that there are likely complementary mechanisms that lead to effector functions.

\section{Reconciling Antibody-Antigen and Antibody-Fc $\gamma$ R Structures}

Given the above discussions, we are led to the idea that antibody angle-of-approach and Fc presentation may indeed play an important role in how well an antibody performs NK cell ADCC. Many structures of antibodies in complex with viral antigens show that antibody Fab can bind at multiple angles-of-approach (Figure 4) (102). This may suggest that the Fc domains of these antibodies are differentially displayed to the immune system as well. How close antigens are to each other, as well as their individual size and shape, could influence how Fc domains are presented as well as the level of avidity experienced (Figure 11A). There is some evidence to suggest that where an antibody binds on antigen may influence innate effector activity for HIV (261), influenza $(262,263)$ and Ebola viruses $(104,264)$, among other examples, but there is not yet convincing molecular data to provide a general model that ties these observations together.

Given the space requirements for receptor signaling to occur between cells, along with the details of structures of both Fabantigen and $\mathrm{Fc}-\mathrm{Fc} \gamma \mathrm{R}$ complexes, there is some suggestion that antibody $\mathrm{Fc}$ and upper-hinge must be presented in a specific way in order for Fc $\gamma$ Rs to recognize them, with the Fc folded over parallel to the effector cell surface (Figures 8B, 9B,C) $(2,12)$. This provides space for every type of $\mathrm{Fc} \gamma \mathrm{R}$ so far described to dimerize in the extracellular region without clashing with bound Fc (Figure 9B). This type of binding is well-suited to antibody structure, which is a unique ligand because of flexibility between antigen and receptor binding domains provided by hingeregions. The degree of flexibility can vary depending on subclass and may correlate with $\mathrm{Fc} \gamma \mathrm{R}$ binding and activation activity. In this model, antibodies could be quite effective at assembling the ADCC activation complex over a wide range of antibody binding angles but may be inhibitory in certain situations (Figure 11B). Additionally, this model also provides for the tuning of activation that could result from less than ideal but still permissive geometries of Fc $\gamma \mathrm{R}$ dimer assembly. However, there are currently no structures of full-length antibody bound to antigen and/or Fc $\gamma$ Rs that would provide the types of details required to reconcile structures of isolated domains in the context of the IS. This field is ripe for discovery and will benefit from future studies that reflect those already accomplished in the $\mathrm{T}$ cell field.

\section{NEXT-GENERATION APPROACHES TO STUDYING NK CELL ADCC}

Much of our understanding of NK cell ADCC, as well as antibody effector function in general, is based on individual biochemical studies or fragmented structural biology. Tying these data together is proving to be difficult and is only beginning to paint a picture that seems pervasive throughout immunology, which is that the immune system is dynamic and variable as well as extensively complex. Therefore, many scientists are beginning to rethink altogether how they approach such difficult questions as those regarding antibody effector function. The next wave of impactful research toward defining realistic and meaningful hypotheses about NK cell function and how to design better therapeutics will almost certainly derive from taking a "bigger picture" approach, such as offered from omics-type studies. Below, I will describe what these approaches are and how they are being used to answer questions regarding NK cell activation.

\section{Transcriptomics, Proteomics, and Metabolomics}

The term "omics" refers to the collective, encompassing and complete study of a particular aspect of biology (265). The major contributors to integrative omics techniques, now referred to as "systems biology," are genomics, transcriptomics, proteomics and metabolomics. These techniques refer to, respectively, the collective and unbiased study of the genes, RNA, proteins and metabolites that make up single cells, tissues or whole organisms $(266,267)$.

Historically, these fields have been quite niche owing to the immense amount of time, expertise and expense associated with using any one of them for analyzing a biological question. For example, sequencing the first human genome is estimated to have cost $\$ 2.7$ billion US dollars and took nearly 15 years to complete. However, advances in technology have not only made these techniques much cheaper and faster, but they are now accessible to nearly any scientist in any field. Much of this success has stemmed from advances in computing, automation and bioinformatics that can handle the massive amounts of samples and data needed to be analyzed. Only recently have these techniques found a foothold in the service-based scientific industry as well as core technologies at many academic institutes. We are now beginning to see immunologists exploit omics as a means of hypothesis generation and an exciting new way to tackle the study of disease, donor immune response variability and mining for distinct cellular subsets (268).

\section{Omics Studies on NK Cell Activation}

Historically, NK cells are distinguished by cell surface markers which tend to lump NK cells into two populations as cytotoxic and regulatory, CD56 $6^{\text {bright }}$ and $\mathrm{CD} 56^{\mathrm{dim}}$, respectively (35). However, transcriptomic profiles of NK cells are beginning to demonstrate a wide range of heterogeneity within NK cell populations. For example, one study utilized single cell RNA sequencing (scRNA seq) to determine transitional populations of NK cells within bone marrow and PB that exist between these two examples (269). Another group demonstrated that NK cells exhibit organ-specific transcriptional profiles (270). Overall, these studies indicate an ability of NK cells to adapt to their location and to maintain plasticity during development. Additionally, transcriptomics has been able to distinguish up to 29 different immune cells types based off of their gene expression profiles, offering a useful tool to study NK cell activation in the context of multiple immune cells or within a whole organism $(271,272)$.

NK cell activation has also been shown to induce unique transcriptional profiles depending on the type of activation 
A

\section{Antigen influence on Fc $\gamma R$ assembly}
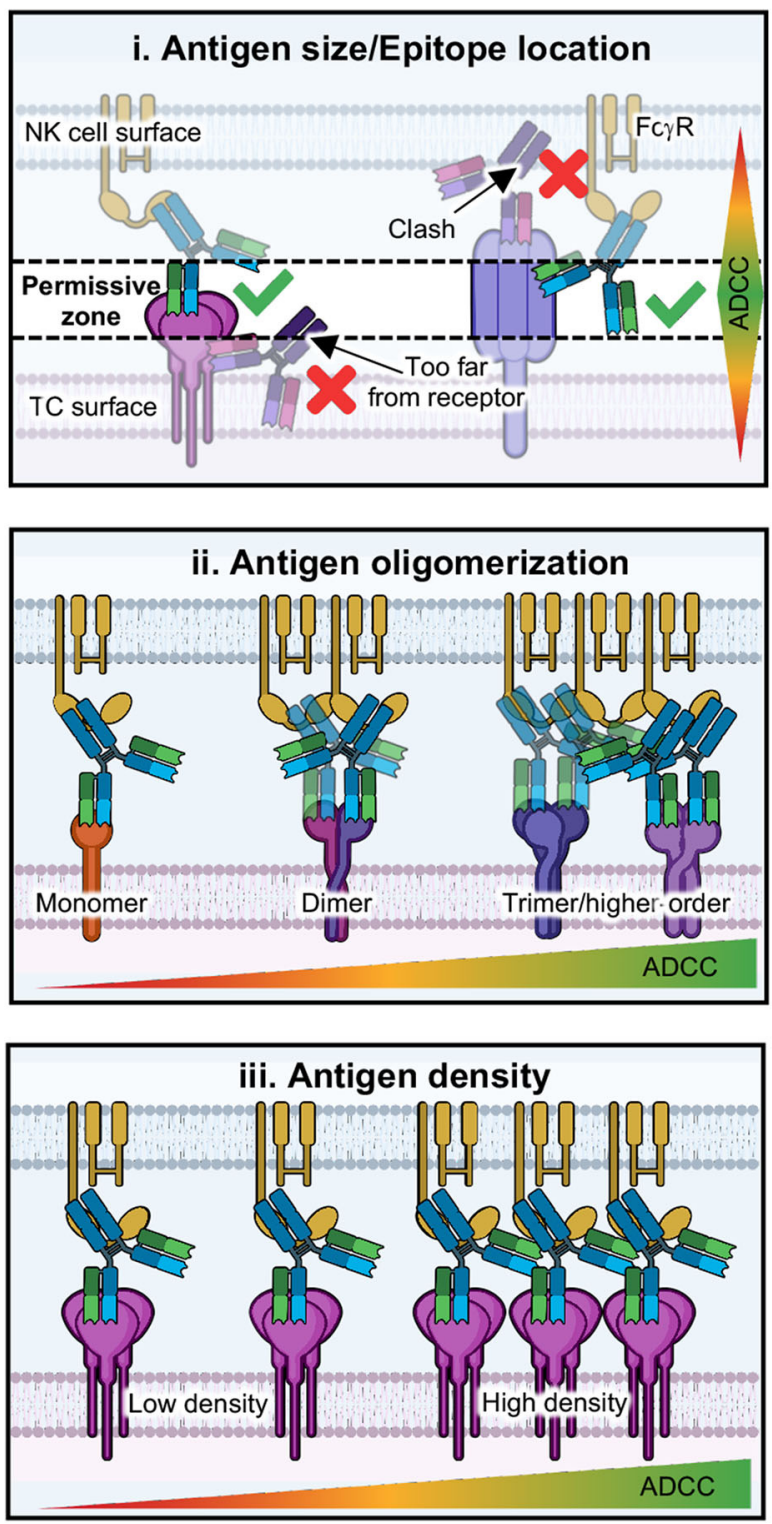

B

Tuning ADCC by antibody angle-of-approach
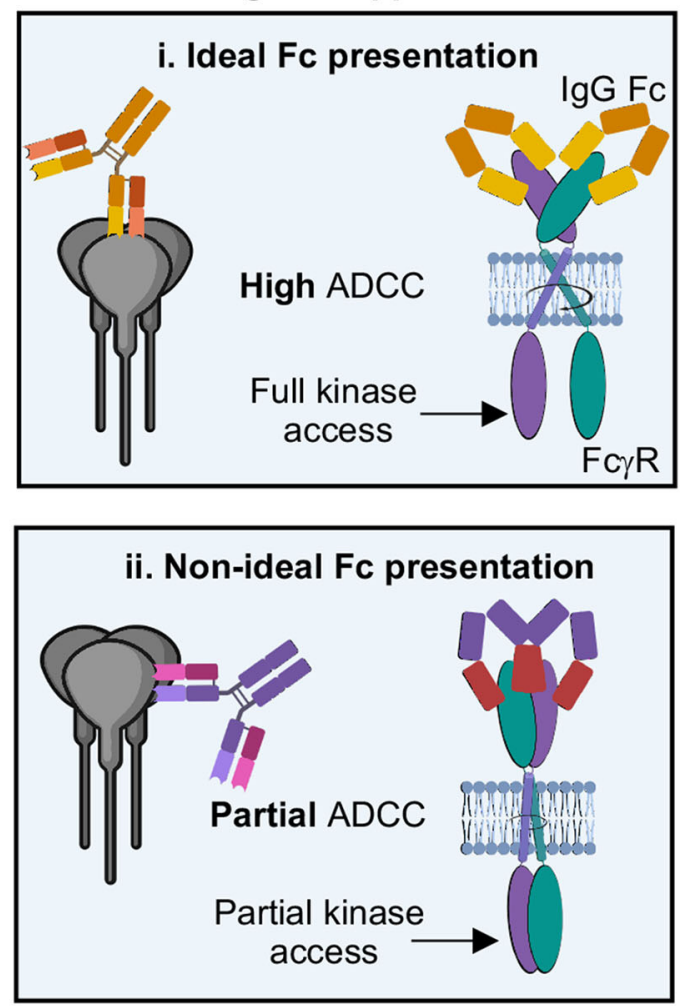

iii. Non-permissive Fc presentation

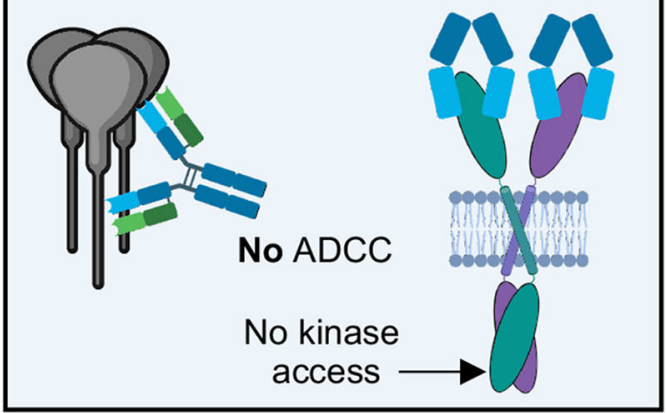

FIGURE 11 | Proposed model of antibody tuning ADCC through activation complex geometry. (A) The immune synapse involves a finite distance between target and effector cell; therefore, the spacing requirements present a "permissive zone" in which antibodies can bind. (i) antigens that are short (i.e., Ebola GP) require antibodies to bind to epitopes on the top of the antigen, while antigens that are longer (i.e., influenza HA), require antibodies to bind lower down on the antigen in order for proper binding to FcyRs. (ii) Antigens that are monomeric may be less likely to facilitate FcyR dimerization/aggregation, while those with higher oligomers present multiple epitopes that increase avidity and chances for Fc $\gamma R$ clustering. (iii) Antigens that are of low density may prevent ADCC due to the inability for enough Fc $\gamma$ Rs to cluster. Conversely, those with higher antigen density present more opportunities for antibodies to induce FcyR clustering and thus higher levels of ADCC. (B) (i) If antibodies bind to antigen in an epitope that presents Fc domains in a way that allows Fc $\gamma$ Rs to dimerize in an ideal way, then intracellular domains can be properly phosphorylated and ADCC is potent. (ii) Potentially, antibodies could bind at non-ideal epitopes, but this may still allow FcyR dimerization, although non-ideally thus preventing full intracellular domain signaling motifs from forming, resulting in partial ADCC. (iii) Some epitopes may present antibody FC in geometries that physically will not allow Fc $\gamma$ R dimerization, thus blocking kinase access and resulting in no ADCC.

stimulus (97). For example, comparison of ADCC, cytokine and direct activation of primary NK cells showed unique gene expression profiles and differential expression of genes commonly associated with NK cell activation (196). Further, HIV infected individuals have NK cells that differ in their activation profiles from healthy donors, indicating that viral infection can alter NK cell activity. This has similarly been demonstrated for CMV infected individuals, where NK cells can adapt over time 
and act more like an adaptive immune cell (273). These type of RNA seq studies expose the subtleties in NK cell activity that can be distinguished by gene expression data.

Proteomic analysis serves as an important way to understand the relationships to gene expression data. The earliest studies of proteomes in NK cells utilized gel electrophoresis to identify membrane enriched proteins, differences in proteins found in activated vs. resting NK cells as well as the identity of microvesicle enriched proteins $(274,275)$. As technology has advanced, larger numbers of proteins have been identified in an unbiased manner, demonstrating the growing utility of proteomics $(276,277)$. A more recent study used proteomic analysis to identify proteins important for NK cell proliferation and pointed a pathway toward increasing the activity of NK cells in a tumor model through therapeutic blockade (278).

Metabolic studies have also revealed a new aspect of NK cell biology and differentiation based on the influence of metabolic factors outside of traditional routes of cellular influence, and these studies have been well-reviewed recently (279-282). Indeed, large differences in metabolic processes have been identified within NK cell subsets. These differences can help distinguish the regulatory, cytotoxic, and memory functions of NK cells. Robust metabolism is essential for efficient cytotoxicity, but metabolic evidence suggests that activated NK cells use alternative routes for oxidative phosphorylation $(279,280)$. Generally, our knowledge of NK cell metabolism is quite limited and has left many questions unaddressed, such as the role of metabolism in organ specific and tissue resident NK cells or whether metabolism can be used to modulate immunotherapies. Further, this field has not tapped into the robust tools of metabolomics yet, which could provide much broader in vivo based knowledge. Although, the field of discovery-based metabolomics is becoming a more accessible technique, it unfortunately still requires large amounts of starting material, which can be inhibitory in certain experimental setups.

\section{CLOSING REMARKS}

So, what does make an effective antibody for recruiting NK cell ADCC? Unsurprisingly, the answer to that question remains incomplete, but what is clear is that fully understanding the underlying mechanisms of antibody effector functions is a complex and difficult task. While this review was certainly not meant to be comprehensive, it was meant to set a stage for understanding the more subtle roles of the molecular underpinnings that seed $\mathrm{NK}$ cell activation in the context of ADCC, as well as to provide a perspective from the point-ofview of structural biology. The roles of structural and biophysical constraints entailed in antibody-based cellular activation have historically been overlooked, and subsequently poorly explored and understood. When developing an antibody with therapeutic potential for NK cell recruitment, one must ask many questions beyond simply "what is the target?" For example, where exactly does this antibody bind? What does the target look like? How will the antibody coordinate activating ligands as a full IgG? How will

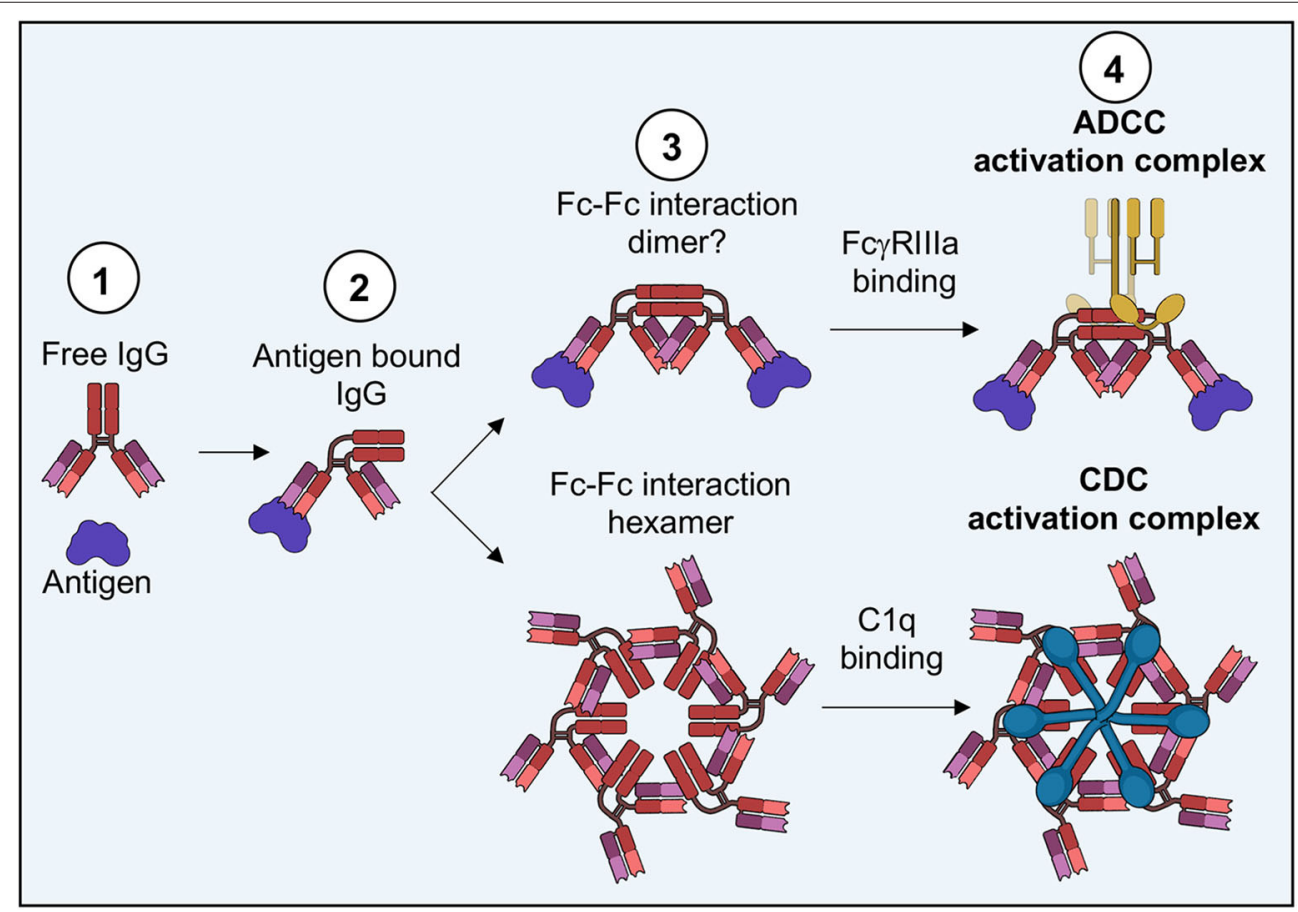

FIGURE 12 | Potential model for lgG effector function fate. (1) Free lgG binds to antigen, (2) causing a change in presentation of the lgG Fc domain. (3) Depending on the arrangement of antigen and/or antibody phenotype, Fc-Fc interactions are facilitated in different oligomeric arrangements. (4) Specific arrangements of Fc-Fc domains influence the binding of Fc $\gamma R$ s or $\mathrm{C} 1 \mathrm{q}$, thus resulting in ADCC, CDC or potentially other effector functions. 
this interplay with the rest of the IS? How will these factors affect the dynamics and coordination of activation?

These types of considerations are important because we have learned from experience that in vitro activity and validation have not always translated well to the clinic. While brute force in evaluating many different potential targets and antibodies is certainly a way to address the gap in treatment for many diseases, a far more cost effective and long-term solution is to rethink how to approach antibody therapeutic research. While comparing autoimmune disease, genetic disorders, cancer and pathogenic infection is difficult to do, the human immune system is designed to be a one stop shop for handling all of these conditions. Therefore, tackling how to harness that power should be, in theory at least, straightforward to do once we gain a better understanding of how it operates.

By returning to the basic biology of NK cell activity, and understanding the molecular nature of activation, we can develop more broadly applicable principles of antibody function and correlates of protection that can be consistently relied upon. Already, the many advances pointed out in this review begin to paint a picture of a more concerted mechanism for how antibodies function post-antigen binding, offering an exciting potential model for antibody effector fate (Figure 12). By combining this simple model with increasing knowledge regarding antibody/receptor glycosylation, as well as the more complex functions of tissue resident immune cells, engineering antibody function may become much more straightforward.

In the future, access to many of the more complex applications discussed here, such as single cell transcriptomics and MINFLUX live cell nanoscopy, may become more commonplace as

\section{REFERENCES}

1. Nimmerjahn F, Ravetch JV. Fcgamma receptors as regulators of immune responses. Nat Rev Immunol. (2008) 8:34-47. doi: 10.1038/nri2206

2. Patel KR, Roberts JT, Barb AW. Multiple variables at the leukocyte cell surface impact Fc gamma receptor-dependent mechanisms. Front Immunol. (2019) 10:223. doi: 10.3389/fimmu.2019.00223

3. Abel AM, Yang C, Thakar MS, Malarkannan S. Natural killer cells: development, maturation, clinical utilization. Front Immunol. (2018) 9:1869. doi: 10.3389/fimmu.2018.01869

4. Shimasaki N, Jain A, Campana D. NK cells for cancer immunotherapy. Nat Rev Drug Discov. (2020) 19:200-18. doi: 10.1038/s41573-019-0052-1

5. Wagstaffe HR, Mooney JP, Riley EM, Goodier MR. Vaccinating for natural killer cell effector functions. Clin Transl Immunol. (2018) 7:e1010. doi: $10.1002 /$ cti2.1010

6. Hodgins JJ, Khan ST, Park MM, Auer RC, Ardolino M. Killers 2.0: NK cell therapies at the forefront of cancer control. J Clin Invest. (2019) 129:3499510. doi: 10.1172/JCI129338

7. Dustin ML, Depoil D. New insights into the $T$ cell synapse from single molecule techniques. Nat Rev Immunol. (2011) 11:672-84. doi: $10.1038 /$ nri3066

8. Fooksman DR, Vardhana S, Vasiliver-Shamis G, Liese J, Blair DA, Waite J, et al. Functional anatomy of $\mathrm{T}$ cell activation and synapse formation. Annu Rev Immunol. (2010) 28:79-105. doi: 10.1146/annurev-immunol-030409-101308

9. Huppa JB, Davis MM. T-cell-antigen recognition and the immunological synapse. Nat Rev Immunol. (2003) 3:973-83. doi: 10.1038/nri1245 technology becomes cheaper and computer processing power become more powerful and widely available. With access to such technologies, immunologists can add new layers to their understanding of how molecular perturbations affect higher order cellular functions. This density of information will make understanding antibody function in vivo much easier, by building a basis of understanding across biological scales up to the organismal level.

\section{AUTHOR CONTRIBUTIONS}

The author confirms being the sole contributor of this work and has approved it for publication.

\section{FUNDING}

CHAVD: This work was funded by Cooperative Agreement award UM1 AI144462 in partnership with the Division of AIDS, NIAID.

\section{ACKNOWLEDGMENTS}

I would like to thank Dr. Andrew Ward of Scripps Research for help with editing this review and his generous guidance. I would also like to thank Dr. Emily Mace of Columbia University and Dr. Silke Paust of Scripps Research for offering their expertise and helpful discussions leading to the assembly of this review. Figures generated with BioRender were completed with permission under academic licensing. Figures including structures were generated using UCSF Chimera.

10. Onnis A, Baldari CT. Orchestration of immunological synapse assembly by vesicular trafficking. Front Cell Dev Biol. (2019) 7:110. doi: 10.3389/fcell.2019.00110

11. Lu RM, Hwang YC, Liu IJ, Lee CC, Tsai HZ, Li HJ, et al. Development of therapeutic antibodies for the treatment of diseases. J Biomed Sci. (2020) 27:1. doi: 10.1186/s12929-019-0592-z

12. Woof JM, Burton DR. Human antibody-Fc receptor interactions illuminated by crystal structures. Nat Rev Immunol. (2004) 4:89-99. doi: 10.1038/nri1266

13. Hibbs ML, Selvaraj P, Carpen O, Springer TA, Kuster H, Jouvin MH, et al. Mechanisms for regulating expression of membrane isoforms of $\mathrm{Fc}$ gamma RIII (CD16). Science. (1989) 246:1608-11. doi: 10.1126/science.25 31918

14. Lanier LL, Yu G, Phillips JH. Co-association of CD3 zeta with a receptor (CD16) for IgG Fc on human natural killer cells. Nature. (1989) 342:803-5. doi: $10.1038 / 342803 \mathrm{a} 0$

15. Nimmerjahn F, Ravetch JV. Fcgamma receptors: old friends and new family members. Immunity. (2006) 24:19-28. doi: 10.1016/j.immuni.2005.11.010

16. Aleyd E, Heineke MH, van Egmond M. The era of the immunoglobulin A Fc receptor FcalphaRI; its function and potential as target in disease. Immunol Rev. (2015) 268:123-38. doi: 10.1111/imr.12337

17. Bakema JE, van Egmond M. The human immunoglobulin A Fc receptor FcalphaRI: a multifaceted regulator of mucosal immunity. Mucosal Immunol. (2011) 4:612-24. doi: 10.1038/mi.2011.36

18. Herr AB, Ballister ER, Bjorkman PJ. Insights into IgA-mediated immune responses from the crystal structures of human FcalphaRI and its complex with IgA1-Fc. Nature. (2003) 423:614-20. doi: 10.1038/nature 01685 
19. Garman SC, Wurzburg BA, Tarchevskaya SS, Kinet JP, Jardetzky TS. Structure of the $\mathrm{Fc}$ fragment of human IgE bound to its high-affinity receptor Fc epsilonRI alpha. Nature. (2000) 406:259-66. doi: 10.1038/35018500

20. Kawakami T, Blank U. From IgE to omalizumab. J Immunol. (2016) 197:4187-92. doi: 10.4049/jimmunol.1601476

21. Turner H, Kinet JP. Signalling through the high-affinity IgE receptor Fc epsilonRI. Nature. (1999) 402:B24-30. doi: 10.1038/35037021

22. Li Y, Wang G, Li N, Wang Y, Zhu Q, Chu H, et al. Structural insights into immunoglobulin M. Science. (2020) 367:1014-7. doi: $10.1126 /$ science.aaz5425

23. Liu J, Wang $\mathrm{Y}$, Xiong E, Hong R, Lu Q, Ohno H, et al. Role of the IgM Fc receptor in immunity and tolerance. Front Immunol. (2019) 10:529. doi: 10.3389/fimmu.2019.00529

24. Gutzeit C, Chen K, Cerutti A. The enigmatic function of IgD: some answers at last. Eur J Immunol. (2018) 48:1101-13. doi: 10.1002/eji.201646547

25. Rudders RA, Andersen J. IgD-Fc receptors on normal and neoplastic human B lymphocytes. Clin Exp Immunol. (1982) 50:579-86.

26. Martins JP, Kennedy PJ, Santos HA, Barrias C, Sarmento B. A comprehensive review of the neonatal $\mathrm{Fc}$ receptor and its application in drug delivery. Pharmacol Ther. (2016) 161:22-39. doi: 10.1016/j.pharmthera.2016.03.007

27. Simister NE, Rees AR. Isolation and characterization of an $\mathrm{Fc}$ receptor from neonatal rat small intestine. Eur J Immunol. (1985) 15:733-8. doi: $10.1002 /$ eji.1830150718

28. Shibuya A, Honda S. Molecular and functional characteristics of the Fcalpha/muR, a novel $F_{c}$ receptor for IgM and IgA. Springer Semin Immunopathol. (2006) 28:377-82. doi: 10.1007/s00281-006-0050-3

29. Stadtmueller BM, Huey-Tubman KE, Lopez CJ, Yang Z, Hubbell WL, Bjorkman PJ. The structure and dynamics of secretory component and its interactions with polymeric immunoglobulins. Elife. (2016) 5:e10640. doi: $10.7554 /$ eLife. 10640

30. Turula $\mathrm{H}$, Wobus $\mathrm{CE}$. The role of the polymeric immunoglobulin receptor and secretory immunoglobulins during mucosal infection and immunity. Viruses. (2018) 10:237. doi: 10.3390/v10050237

31. Bruhns P, Iannascoli B, England P, Mancardi DA, Fernandez N, Jorieux $\mathrm{S}$, et al. Specificity and affinity of human Fcgamma receptors and their polymorphic variants for human IgG subclasses. Blood. (2009) 113:3716-25. doi: 10.1182/blood-2008-09-179754

32. Siegrist C. Vaccine immunology. In: Plotkin SA, Orenstein WA, Offit PA, editors. Plotkin's Vaccines. Philadelphia, PA: Elsevier Publishing Group (2018). p. 16-34.e7. doi: 10.1016/B978-0-323-35761-6.00002-X

33. Burton DR, Antibodies, viruses and vaccines. Nat Rev Immunol. (2002) 2:706-13. doi: 10.1038/nri891

34. Yu J, Freud AG, Caligiuri MA. Location and cellular stages of natural killer cell development. Trends Immunol. (2013) 34:573-82. doi: 10.1016/j.it.2013.07.005

35. Luetke-Eversloh M, Killig M, Romagnani C. Signatures of human NK cell development and terminal differentiation. Front Immunol. (2013) 4:499. doi: $10.3389 /$ fimmu.2013.00499

36. Alderson KL, Sondel PM. Clinical cancer therapy by NK cells via antibody-dependent cell-mediated cytotoxicity. J Biomed Biotechnol. (2011) 2011:379123. doi: 10.1155/2011/379123

37. Subedi GP, Barb AW. CD16a with oligomannose-type N-glycans is the only "low-affinity" Fc gamma receptor that binds the IgG crystallizable fragment with high affinity in vitro. J Biol Chem. (2018) 293:16842-50. doi: 10.1074/jbc.RA118.004998

38. Hanson QM, Barb AW. A perspective on the structure and receptor binding properties of immunoglobulin G Fc. Biochemistry. (2015) 54:293142. doi: 10.1021/acs.biochem.5b00299

39. Herzik MA Jr, Wu M, Lander GC. High-resolution structure determination of sub-100 kDa complexes using conventional cryo-EM. Nat Commun. (2019) 10:1032. doi: 10.1038/s41467-019-08991-8

40. Lyumkis D. Challenges and opportunities in cryo-EM single-particle analysis. J Biol Chem. (2019) 294:5181-97. doi: 10.1074/jbc.REV118.005602

41. Merk A, Bartesaghi A, Banerjee S, Falconieri V, Rao P, Davis MI, et al. Breaking Cryo-EM resolution barriers to facilitate drug discovery. Cell. (2016) 165:1698-707. doi: 10.1016/j.cell.2016.05.040

42. Lu J, Chu J, Zou Z, Hamacher NB, Rixon MW, Sun PD. Structure of FcgammaRI in complex with $\mathrm{Fc}$ reveals the importance of glycan recognition for high-affinity IgG binding. Proc Natl Acad Sci USA. (2015) 112:833-8. doi: $10.1073 /$ pnas. 1418812112

43. Subedi GP, Barb AW. The immunoglobulin G1 N-glycan composition affects binding to each low affinity Fc gamma receptor. Mabs-Austin. (2016) 8:151224. doi: 10.1080/19420862.2016.1218586

44. Subedi GP, Barb AW. The structural role of antibody Nglycosylation in receptor interactions. Structure. (2015) 23:1573-83. doi: 10.1016/j.str.2015.06.015

45. Schwab I, Nimmerjahn F. Intravenous immunoglobulin therapy: how does IgG modulate the immune system? Nat Rev Immunol. (2013) 13:176-89. doi: $10.1038 /$ nri3401

46. Rudd PM, Elliott T, Cresswell P, Wilson IA, Dwek RA. Glycosylation and the immune system. Science. (2001) 291:2370-6. doi: $10.1126 /$ science. 291.5512 .2370

47. Pereira NA, Chan KF, Lin PC, Song Z. The "less-is-more" in therapeutic antibodies: afucosylated anti-cancer antibodies with enhanced antibodydependent cellular cytotoxicity. Mabs-Austin. (2018) 10:693-711. doi: $10.1080 / 19420862.2018 .1466767$

48. Ferrara C, Grau S, Jager C, Sondermann P, Brunker P, Waldhauer I, et al. Unique carbohydrate-carbohydrate interactions are required for high affinity binding between FcgammaRIII and antibodies lacking core fucose. Proc Natl Acad Sci USA. (2011) 108:12669-74. doi: 10.1073/pnas.11084 55108

49. Falconer DJ, Subedi GP, Marcella AM, Barb AW. Antibody fucosylation lowers the FcgammaRIIIa/CD16a affinity by limiting the conformations sampled by the N162-Glycan. ACS Chem Biol. (2018) 13:2179-89. doi: $10.1021 /$ acschembio. 8 b00342

50. Hayes JM, Wormald MR, Rudd PM, Davey GP. Fc gamma receptors: glycobiology and therapeutic prospects. J Inflamm Res. (2016) 9:209-19. doi: $10.2147 /$ JIR.S121233

51. Rosales C. Fcgamma receptor heterogeneity in leukocyte functional responses. Front Immunol. (2017) 8:280. doi: 10.3389/fimmu.2017.00280

52. Rothenberg EV. Lineage determination in the immune system. Immunol Rev. (2010) 238:5-11. doi: 10.1111/j.1600-065X.2010.00965.x

53. Mercier FE, Ragu C, Scadden DT. The bone marrow at the crossroads of blood and immunity. Nat Rev Immunol. (2012) 12:49-60. doi: $10.1038 /$ nri3132

54. Cichocki F, Grzywacz B, Miller JS. Human NK cell development: one road or many? Front Immunol. (2019) 10:2078. doi: 10.3389/fimmu.2019.02078

55. Freud AG, Mundy-Bosse BL, Yu J, Caligiuri MA. The broad spectrum of human natural killer cell diversity. Immunity. (2017) 47:820-33. doi: 10.1016/j.immuni.2017.10.008

56. Filipovic I, Sonnerborg I, Strunz B, Friberg D, Cornillet M, Hertwig L, et al. 29-Color flow cytometry: unraveling human liver NK cell repertoire diversity. Front Immunol. (2019) 10:2692. doi: 10.3389/fimmu.2019. 02692

57. Peng H, Tian Z. Diversity of tissue-resident NK cells. Semin Immunol. (2017) 31:3-10. doi: 10.1016/j.smim.2017.07.006

58. Horowitz A, Strauss-Albee DM, Leipold M, Kubo J, Nemat-Gorgani N, Dogan OC, et al. Genetic and environmental determinants of human NK cell diversity revealed by mass cytometry. Sci Transl Med. (2013) 5:208ra145. doi: 10.1126/scitranslmed.3006702

59. Bjorkstrom NK, Ljunggren HG, Michaelsson J. Emerging insights into natural killer cells in human peripheral tissues. Nat Rev Immunol. (2016) 16:310-20. doi: 10.1038/nri.2016.34

60. Farag SS, Caligiuri MA. Human natural killer cell development and biology. Blood Rev. (2006) 20:123-37. doi: 10.1016/j.blre.2005.10.001

61. Cooper MA, Fehniger TA, Caligiuri MA. The biology of human natural killer-cell subsets. Trends Immunol. (2001) 22:633-40. doi: 10.1016/S1471-4906(01)02060-9

62. Zhang C, Oberoi P, Oelsner S, Waldmann A, Lindner A, Tonn T, et al. Chimeric antigen receptor-engineered NK-92 cells: an off-theshelf cellular therapeutic for targeted elimination of cancer cells and induction of protective antitumor immunity. Front Immunol. (2017) 8:533. doi: 10.3389/fimmu.2017.00533

63. Gong JH, Maki G, Klingemann HG. Characterization of a human cell line (NK-92) with phenotypical and functional characteristics of activated natural killer cells. Leukemia. (1994) 8:652-8. 
64. Dogra P, Rancan C, Ma W, Toth M, Senda T, Carpenter DJ, et al. Tissue determinants of human NK cell development, function, and residence. Cell. (2020) 180:749-63.e13. doi: 10.1016/j.cell.2020.01.022

65. Rajalingam R. Diversity of killer cell immunoglobulin-like receptors and disease. Clin Lab Med. (2018) 38:637-53. doi: 10.1016/j.cll.2018.08.001

66. Sun JC, Lopez-Verges S, Kim CC, DeRisi JL, Lanier LL. NK cells and immune "memory". J Immunol. (2011) 186:1891-7. doi: 10.4049/jimmunol.1003035

67. Paust S, von Andrian UH. Natural killer cell memory. Nat Immunol. (2011) 12:500-8. doi: 10.1038/ni.2032

68. Jay JW, Bray B, Qi Y, Igbinigie E, Wu H, Li J, et al. IgG antibody 3D structures and dynamics. Antibodies. (2018) 7:18. doi: 10.3390/antib7020018

69. Lanier LL, Yu G, Phillips JH. Analysis of Fc gamma RIII (CD16) membrane expression and association with CD3 zeta and Fc epsilon RI-gamma by site-directed mutation. J Immunol. (1991) 146:1571-6.

70. Wirthmueller U, Kurosaki T, Murakami MS, Ravetch JV. Signal transduction by Fc gamma RIII (CD16) is mediated through the gamma chain. J Exp Med. (1992) 175:1381-90. doi: 10.1084/jem.175.5.1381

71. Paul WE, Seder RA. Lymphocyte responses and cytokines. Cell. (1994) 76:241-51. doi: 10.1016/0092-8674(94)90332-8

72. Dustin ML, Olszowy MW, Holdorf AD, Li J, Bromley S, Desai $\mathrm{N}$, et al. A novel adaptor protein orchestrates receptor patterning and cytoskeletal polarity in T-cell contacts. Cell. (1998) 94:667-77. doi: 10.1016/S0092-8674(00)81608-6

73. Dustin ML. The immunological synapse. Cancer Immunol Res. (2014) 2:1023-33. doi: 10.1158/2326-6066.CIR-14-0161

74. Orange JS. Formation and function of the lytic NK-cell immunological synapse. Nat Rev Immunol. (2008) 8:713-25. doi: 10.1038/nri2381

75. Mukherjee M, Mace EM, Carisey AF, Ahmed N, Orange JS. Quantitative imaging approaches to study the CAR immunological synapse. Mol Ther. (2017) 25:1757-68. doi: 10.1016/j.ymthe.2017.06.003

76. Mace EM, Orange JS. New views of the human NK cell immunological synapse: recent advances enabled by super- and high-resolution imaging techniques. Front Immunol. (2012) 3:421. doi: 10.3389/fimmu.2012.00421

77. Orange JS, Harris KE, Andzelm MM, Valter MM, Geha RS, Strominger JL. The mature activating natural killer cell immunologic synapse is formed in distinct stages. Proc Natl Acad Sci USA. (2003) 100:14151-6. doi: 10.1073/pnas.1835830100

78. Mace EM, Orange JS. Multiple distinct NK-cell synapses. Blood. (2011) 118:6475-6. doi: 10.1182/blood-2011-10-381392

79. Warren HS, Altin JG, Waldron JC, Kinnear BF, Parish CR. A carbohydrate structure associated with CD15 (Lewis $\mathrm{x}$ ) on myeloid cells is a novel ligand for human CD2. J Immunol. (1996) 156:2866-73.

80. Frey M, Packianathan NB, Fehniger TA, Ross ME, Wang WC, Stewart CC, et al. Differential expression and function of L-selectin on CD56bright and CD56dim natural killer cell subsets. J Immunol. (1998) 161:400-8.

81. Dhar P, Wu JD. NKG2D and its ligands in cancer. Curr Opin Immunol. (2018) 51:55-61. doi: 10.1016/j.coi.2018.02.004

82. Fruh K, Gruhler A, Krishna RM, Schoenhals GJ. A comparison of viral immune escape strategies targeting the MHC class I assembly pathway. Immunol Rev. (1999) 168:157-66. doi: 10.1111/j.1600-065X.1999. tb01290.x

83. Shifrin N, Raulet DH, Ardolino M. NK cell self tolerance, responsiveness and missing self recognition. Semin Immunol. (2014) 26:138-44. doi: 10.1016/j.smim.2014.02.007

84. Yeap WH, Wong KL, Shimasaki N, Teo EC, Quek JK, Yong HX, et al. CD16 is indispensable for antibody-dependent cellular cytotoxicity by human monocytes. Sci Rep. (2016) 6:34310. doi: 10.1038/srep34310

85. Zheng P, Bertolet G, Chen Y, Huang S, Liu D. Super-resolution imaging of the natural killer cell immunological synapse on a glass-supported planar lipid bilayer. J Vis Exp. (2015) 11:52502. doi: 10.3791/52502

86. Liu D, Peterson ME, Long EO. The adaptor protein Crk controls activation and inhibition of natural killer cells. Immunity. (2012) 36:600-11. doi: 10.1016/j.immuni.2012.03.007

87. Hadad U, Thauland TJ, Martinez OM, Butte MJ, Porgador A, Krams SM. NKp46 clusters at the immune synapse and regulates NK cell polarization. Front Immunol. (2015) 6:495. doi: 10.3389/fimmu.2015.00495

88. Fritzsche M, Fernandes RA, Chang VT, Colin-York H, Clausen MP, Felce $\mathrm{JH}$, et al. Cytoskeletal actin dynamics shape a ramifying actin network underpinning immunological synapse formation. Sci Adv. (2017) 3:e1603032. doi: 10.1126/sciadv.1603032

89. Carisey AF, Mace EM, Saeed MB, Davis DM, Orange JS. Nanoscale dynamism of actin enables secretory function in cytolytic cells. Curr Biol. (2018) 28:489-502.e9. doi: 10.1016/j.cub.2017.12.044

90. Inoue $H$, Miyaji $M$, Kosugi A, Nagafuku M, Okazaki T, Mimori T, et al. Lipid rafts as the signaling scaffold for NK cell activation: tyrosine phosphorylation and association of LAT with phosphatidylinositol 3-kinase and phospholipase C-gamma following CD2 stimulation. Eur J Immunol. (2002) 32:2188-98. doi: 10.1002/1521-4141(200208)32:8\&lt;2188::AIDIMMU2188\&gt;3.0.CO;2-T

91. Galandrini R, Tassi I, Mattia G, Lenti L, Piccoli M, Frati L, et al. SH2containing inositol phosphatase (SHIP-1) transiently translocates to raft domains and modulates CD16-mediated cytotoxicity in human NK cells. Blood. (2002) 100:4581-9. doi: 10.1182/blood-2002-04-1058

92. Alter G, Malenfant JM, Altfeld M. CD107a as a functional marker for the identification of natural killer cell activity. J Immunol Methods. (2004) 294:15-22. doi: 10.1016/j.jim.2004.08.008

93. Netter P, Anft M, Watzl C. Termination of the activating NK cell immunological synapse is an active and regulated process. J Immunol. (2017) 199:2528-35. doi: 10.4049/jimmunol.1700394

94. Srpan K, Ambrose A, Karampatzakis A, Saeed M, Cartwright ANR, Guldevall K, et al. Shedding of CD16 disassembles the NK cell immune synapse and boosts serial engagement of target cells. J Cell Biol. (2018) 217:3267-83. doi: 10.1083/jcb.201712085

95. Goodier MR, Lusa C, Sherratt S, Rodriguez-Galan A, Behrens R, Riley EM. Sustained immune complex-mediated reduction in CD16 expression after vaccination regulates NK cell function. Front Immunol. (2016) 7:384 doi: 10.3389/fimmu.2016.00384

96. Prager I, Liesche C, van Ooijen H, Urlaub D, Verron Q, Sandstrom $\mathrm{N}$, et al. NK cells switch from granzyme B to death receptor-mediated cytotoxicity during serial killing. J Exp Med. (2019) 216:2113-27. doi: 10.1084/jem.20181454

97. Fehniger TA, Shah MH, Turner MJ, VanDeusen JB, Whitman SP, Cooper MA, et al. Differential cytokine and chemokine gene expression by human NK cells following activation with IL-18 or IL-15 in combination with IL-12: implications for the innate immune response. J Immunol. (1999) 162:451120.

98. Roda JM, Parihar R, Magro C, Nuovo GJ, Tridandapani S, Carson WE III. Natural killer cells produce $\mathrm{T}$ cell-recruiting chemokines in response to antibody-coated tumor cells. Cancer Res. (2006) 66:517-26. doi: 10.1158/0008-5472.CAN-05-2429

99. Somersalo K, Carpen O, Saksela E. Stimulated natural killer cells secrete factors with chemotactic activity, including NAP-1/IL-8, which supports VLA-4- and VLA-5-mediated migration of T lymphocytes. Eur J Immunol. (1994) 24:2957-65. doi: 10.1002/eji.1830241206

100. Bianchi M, Turner HL, Nogal B, Cottrell CA, Oyen D, Pauthner $\mathrm{M}$, et al. Electron-microscopy-based epitope mapping defines specificities of polyclonal antibodies elicited during HIV-1 BG505 envelope trimer immunization. Immunity. (2018) 49:288-300.e8. doi: 10.1016/j.immuni.2018.07.009

101. Nogal B, Bianchi M, Cottrell CA, Kirchdoerfer RN, Sewall LM, Turner $\mathrm{HL}$, et al. Mapping polyclonal antibody responses in non-human primates vaccinated with HIV Env trimer subunit vaccines. Cell Rep. (2020) 30:375565.e7. doi: 10.1016/j.celrep.2020.02.061

102. Murin CD, Wilson IA, Ward AB. Antibody responses to viral infections: a structural perspective across three different enveloped viruses. Nat Microbiol. (2019) 4:734-47. doi: 10.1038/s41564-019-0392-y

103. Lu LL, Suscovich TJ, Fortune SM, Alter G. Beyond binding: antibody effector functions in infectious diseases. Nat Rev Immunol. (2018) 18:46-61. doi: 10.1038/nri.2017.106

104. Saphire EO, Schendel SL, Fusco ML, Gangavarapu K, Gunn BM, Wec AZ, et al. Viral hemorrhagic fever immunotherapeutic, systematic analysis of monoclonal antibodies against ebola virus GP defines features that contribute to protection. Cell. (2018) 174:938-52.e13. doi: 10.1016/j.cell.2018.07.033

105. Temming AR, de Taeye SW, de Graaf EL, de Neef LA, Dekkers G, Bruggeman $\mathrm{CW}$, et al. Functional attributes of antibodies, effector cells, and target 
cells affecting NK cell-mediated antibody-dependent cellular cytotoxicity. $J$ Immunol. (2019) 203:3126-35. doi: 10.4049/jimmunol.1900985

106. Nagelkerke SQ, Schmidt DE, de Haas M, Kuijpers TW. Genetic variation in low-to-medium-affinity fcgamma receptors: functional consequences, disease associations, and opportunities for personalized medicine. Front Immunol. (2019) 10:2237. doi: 10.3389/fimmu.2019.02237

107. Roberts JT, Patel KR, Barb AW. Site-specific N-glycan analysis of antibodybinding Fc gamma receptors from primary human monocytes. Mol Cell Proteomics. (2020) 19:362-74. doi: 10.1074/mcp.RA119.001733

108. Yamaguchi Y, Barb AW. A synopsis of recent developments defining how N-glycosylation impacts immunoglobulin G structure and function. Glycobiology. (2019) 30:214-25. doi: 10.1093/glycob/cwz068

109. Radaev S, Motyka S, Fridman WH, Sautes-Fridman C, Sun PD. The structure of a human type III Fcgamma receptor in complex with Fc. J Biol Chem. (2001) 276:16469-77. doi: 10.1074/jbc.M100350200

110. Patel KR, Roberts JT, Subedi GP, Barb AW. Restricted processing of $\mathrm{CD} 16 \mathrm{a} / \mathrm{Fc}$ gamma receptor IIIa N-glycans from primary human NK cells impacts structure and function. J Biol Chem. (2018) 293:3477-89. doi: 10.1074/jbc.RA117.001207

111. Barb AW, Meng L, Gao Z, Johnson RW, Moremen KW, Prestegard JH. NMR characterization of immunoglobulin G Fc glycan motion on enzymatic sialylation. Biochemistry. (2012) 51:4618-26. doi: 10.1021/bi300319q

112. Barb AW, Prestegard JH. NMR analysis demonstrates immunoglobulin G N-glycans are accessible and dynamic. Nat Chem Biol. (2011) 7:147-53. doi: 10.1038/nchembio.511

113. Roberts JT, Barb AW. A single amino acid distorts the Fc gamma receptor IIIb/CD16b structure upon binding immunoglobulin G1 and reduces affinity relative to CD16a. J Biol Chem. (2018) 293:19899-908. doi: $10.1074 /$ jbc.RA118.005273

114. Le Saux G, Schvartzman M. Advanced materials and devices for the regulation and study of NK cells. Int J Mol Sci. (2019) 20:646. doi: 10.3390/ijms20030646

115. Mace EM, Orange JS. High- and super-resolution microscopy imaging of the NK cell immunological synapse. Methods Mol Biol. (2016) 1441:141-50. doi: 10.1007/978-1-4939-3684-7_12

116. Balagopalan L, Sherman E, Barr VA, Samelson LE. Imaging techniques for assaying lymphocyte activation in action. Nat Rev Immunol. (2011) 11:21-33. doi: $10.1038 /$ nri2903

117. Calvo V, Izquierdo M. Imaging polarized secretory traffic at the immune synapse in living T lymphocytes. Front Immunol. (2018) 9:684. doi: 10.3389/fimmu.2018.00684

118. Kasprowicz R, Rand E, O'Toole PJ, Signoret N. A correlative and quantitative imaging approach enabling characterization of primary cell-cell communication: case of human $\mathrm{CD} 4^{+} \mathrm{T}$ cell-macrophage immunological synapses. Sci Rep. (2018) 8:8003. doi: 10.1038/s41598-018-26172-3

119. Pettmann J, Santos AM, Dushek O, Davis SJ. Membrane ultrastructure and T cell activation. Front Immunol. (2018) 9:2152. doi: 10.3389/fimmu.2018.02152

120. Biggs MJP, Milone MC, Santos LC, Gondarenko A, Wind SJ. High-resolution imaging of the immunological synapse and T-cell receptor microclustering through microfabricated substrates. J R Soc Interface. (2011) 8:1462-71. doi: 10.1098/rsif.2011.0025

121. Jang JH, Huang Y, Zheng P, Jo MC, Bertolet G, Zhu MX, et al. Imaging of cell-cell communication in a vertical orientation reveals high-resolution structure of immunological synapse and novel PD-1 dynamics. J Immunol. (2015) 195:1320-30. doi: 10.4049/jimmunol.1403143

122. Brown AC, Oddos S, Dobbie IM, Alakoskela JM, Parton RM, Eissmann $\mathrm{P}$, et al. Remodelling of cortical actin where lytic granules dock at natural killer cell immune synapses revealed by super-resolution microscopy. PLoS Biol. (2011) 9:e1001152. doi: 10.1371/journal.pbio.10 01152

123. Feng $\mathrm{Y}$, Reinherz EL, Lang MJ. alphabeta $\mathrm{T}$ cell receptor mechanosensing forces out serial engagement. Trends Immunol. (2018) 39:596-609. doi: 10.1016/j.it.2018.05.005

124. Oddos S, Dunsby C, Purbhoo MA, Chauveau A, Owen DM, Neil MA, et al. High-speed high-resolution imaging of intercellular immune synapses using optical tweezers. Biophys J. (2008) 95:L66-8. doi: 10.1529/biophysj.108.143198
125. Forslund E, Guldevall K, Olofsson PE, Frisk T, Christakou AE, Wiklund $\mathrm{M}$, et al. Novel microchip-based tools facilitating live cell imaging and assessment of functional heterogeneity within NK cell populations. Front Immunol. (2012) 3:300. doi: 10.3389/fimmu.2012.00300

126. Christakou AE, Ohlin M, Vanherberghen B, Khorshidi MA, Kadri N, Frisk $\mathrm{T}$, et al. Live cell imaging in a micro-array of acoustic traps facilitates quantification of natural killer cell heterogeneity. Integr Biol. (2013) 5:712-9. doi: 10.1039/c3ib20253d

127. Ozcelik A, Rufo J, Guo F, Gu Y, Li P, Lata J, et al. Acoustic tweezers for the life sciences. Nat Methods. (2018) 15:1021-8. doi: 10.1038/s41592-018$0222-9$

128. Xie Y, Zhao C, Zhao Y, Li S, Rufo J, Yang S, et al. Optoacoustic tweezers: a programmable, localized cell concentrator based on opto-thermally generated, acoustically activated, surface bubbles. Lab Chip. (2013) 13:17729. doi: 10.1039/c3lc00043e

129. Buchegger B, Kreutzer J, Axmann M, Mayr S, Wollhofen R, Plochberger $B$, et al. Proteins on supported lipid bilayers diffusing around proteins fixed on acrylate anchors. Anal Chem. (2018) 90:12372-6. doi: 10.1021/acs.analchem. 8 b02588

130. Collier CP. Bilayer membrane interactions with nanofabricated scaffolds. Chem Phys Lipids. (2015) 192:75-86. doi: 10.1016/j.chemphyslip.2015. 07.013

131. Hirano-Iwata A, Niwano M, Sugawara M. The design of molecular sensing interfaces with lipid-bilayer assemblies. Trac-Trend Anal Chem. (2008) 27:512-20. doi: 10.1016/j.trac.2008.04.006

132. Kaizuka Y, Douglass AD, Varma R, Dustin ML, Vale RD. Mechanisms for segregating $\mathrm{T}$ cell receptor and adhesion molecules during immunological synapse formation in Jurkat T cells. Proc Natl Acad Sci USA. (2007) 104:20296-301. doi: 10.1073/pnas.0710258105

133. Steblyanko M, Anikeeva N, Buggert M, Betts MR, Sykulev Y. Assessment of the synaptic interface of primary human $\mathrm{T}$ cells from peripheral blood and lymphoid tissue. Jove-J Vis Exp. (2018) 30:58143. doi: 10.3791/58143

134. Valvo S, Mayya V, Seraia E, Afrose J, Novak-Kotzer H, Ebner D, et al. Comprehensive analysis of immunological synapse phenotypes using supported lipid bilayers. Methods Mol Biol. (2017) 1584:423-41. doi: 10.1007/978-1-4939-6881-7_26

135. Bartsch P, Walter C, Selenschik P, Honigmann A, Wagner R. Horizontal bilayer for electrical and optical recordings. Materials. (2012) 5:2705-30. doi: 10.3390/ma5122705

136. Wilke RA, Mehta RP, Lupardus PJ, Chen Y, Ruoho AE, Jackson MB. Sigma receptor photolabeling and sigma receptor-mediated modulation of potassium channels in tumor cells. J Biol Chem. (1999) 274:18387-92. doi: $10.1074 /$ jbc.274.26.18387

137. Ferhan AR, Yoon BK, Park S, Sut TN, Chin H, Park JH, et al. Solvent-assisted preparation of supported lipid bilayers. Nat Protoc. (2019) 14:2091-118. doi: 10.1038/s41596-019-0174-2

138. Chikh GG, Li WM, Schutze-Redelmeier MP, Meunier JC, Bally MB. Attaching histidine-tagged peptides and proteins to lipid-based carriers through use of metal-ion-chelating lipids. Biochim Biophys Acta. (2002) 1567:204-12. doi: 10.1016/S0005-2736(02)00618-1

139. Dubacheva GV, Araya-Callis C, Geert Volbeda A, Fairhead M, Codee J, Howarth $\mathrm{M}$, et al. Controlling multivalent binding through surface chemistry: model study on streptavidin. J Am Chem Soc. (2017) 139:4157-67. doi: 10.1021/jacs.7b00540

140. Mossman KD, Campi G, Groves JT, Dustin ML. Altered TCR signaling from geometrically repatterned immunological synapses. Science. (2005) 310:1191-3. doi: 10.1126/science.1119238

141. Culley FJ, Johnson M, Evans JH, Kumar S, Crilly R, Casasbuenas J, et al. Natural killer cell signal integration balances synapse symmetry and migration. PLoS Biol. (2009) 7:e1000159. doi: 10.1371/journal.pbio.1000159

142. Combs CA, Shroff H. Fluorescence microscopy: a concise guide to current imaging methods. Curr Protoc Neurosci. (2017) 79:2.1.1-2.1.2.5. doi: $10.1002 /$ cpns. 29

143. Lambert TJ, Waters JC. Navigating challenges in the application of superresolution microscopy. J Cell Biol. (2017) 216:53-63. doi: 10.1083/jcb.201610011

144. Lichtman JW, Conchello JA. Fluorescence microscopy. Nat Methods. (2005) 2:910-9. doi: $10.1038 /$ nmeth 817 
145. Sanchez E, Liu X, Huse M. Actin clearance promotes polarized dynein accumulation at the immunological synapse. PLoS ONE. (2019) 14:e0210377. doi: 10.1371/journal.pone.0210377

146. Razvag Y, Neve-Oz Y, Sajman J, Yakovian O, Reches M, Sherman E. T cell activation through isolated tight contacts. Cell Rep. (2019) 29:3506-21.e6. doi: 10.1016/j.celrep.2019.11.022

147. Bello-Gamboa A, Izquierdo JM, Velasco M, Moreno S, Garrido A, Meyers L, et al. Imaging the human immunological synapse. J Vis Exp. (2019) 154. doi: $10.3791 / 60312$

148. Carr AR, Ponjavic A, Basu S, McColl J, Santos AM, Davis S, et al. Three-dimensional super-resolution in eukaryotic cells using the double-helix point spread function. Biophys J. (2017) 112:1444-54. doi: 10.1016/j.bpj.2017.02.023

149. Mace EM, Orange JS. Dual channel STED nanoscopy of lytic granules on actin filaments in natural killer cells. Commun Integr Biol. (2012) 5:184-6. doi: $10.4161 /$ cib. 18818

150. Vicidomini G, Bianchini P, Diaspro A. STED super-resolved microscopy. Nat Methods. (2018) 15:173-82. doi: 10.1038/nmeth.4593

151. Nicovich PR, Owen DM, Gaus K. Turning single-molecule localization microscopy into a quantitative bioanalytical tool. Nat Protoc. (2017) 12:45360. doi: 10.1038/nprot.2016.166

152. Lillemeier BF, Mortelmaier MA, Forstner MB, Huppa JB, Groves JT, Davis MM. TCR and Lat are expressed on separate protein islands on T cell membranes and concatenate during activation. Nat Immunol. (2010) 11:906. doi: $10.1038 /$ ni. 1832

153. Galbraith CG, Galbraith JA. Super-resolution microscopy at a glance. J Cell Sci. (2011) 124:1607-11. doi: 10.1242/jcs.080085

154. Toomre D, Bewersdorf J. A new wave of cellular imaging. Annu Rev Cell Dev Biol. (2010) 26:285-314. doi: 10.1146/annurev-cellbio-100109-104048

155. Ritter AT, Asano Y, Stinchcombe JC, Dieckmann NM, Chen BC, GawdenBone $\mathrm{C}$, et al. Actin depletion initiates events leading to granule secretion at the immunological synapse. Immunity. (2015) 42:864-76. doi: 10.1016/j.immuni.2015.04.013

156. Balagopalan L, Yi J, Nguyen T, McIntire KM, Harned AS, Narayan K, et al. Plasma membrane LAT activation precedes vesicular recruitment defining two phases of early T-cell activation. Nat Commun. (2018) 9:2013. doi: 10.1038/s41467-018-04419-x

157. Tachibana C. Democratizing cryo-EM: broadening access to an expanding field. Science. (2020) 367:1391-2. doi: 10.1126/science.367.6484.1394-b

158. Hand E. 'We need a people's cryo-EM.' Scientists hope to bring revolutionary microscope to the masses. Science. (2020) 367:354-8. doi: $10.1126 /$ science.aba9954

159. Callaway E. The revolution will not be crystallized: a new method sweeps through structural biology. Nature. (2015) 525:172-4. doi: 10.1038/525172a

160. Mahamid J, Pfeffer S, Schaffer M, Villa E, Danev R, Cuellar LK, et al. Visualizing the molecular sociology at the HeLa cell nuclear periphery. Science. (2016) 351:969-72. doi: 10.1126/science.aad8857

161. Orlov I, Myasnikov AG, Andronov L, Natchiar SK, Khatter H, Beinsteiner B, et al. The integrative role of cryo electron microscopy in molecular and cellular structural biology. Biol Cell. (2017) 109:81-93. doi: 10.1111/boc.201600042

162. Weber MS, Wojtynek M, Medalia O. Cellular and structural studies of eukaryotic cells by cryo-electron tomography. Cells. (2019) 8:57. doi: $10.3390 /$ cells 8010057

163. Villa E, Schaffer M, Plitzko JM, Baumeister W. Opening windows into the cell: focused-ion-beam milling for cryo-electron tomography. Curr Opin Struct Biol. (2013) 23:771-7. doi: 10.1016/j.sbi.2013.08.006

164. Wolff G, Limpens R, Zheng S, Snijder EJ, Agard DA, Koster AJ, et al. Mind the gap: micro-expansion joints drastically decrease the bending of FIB-milled cryo-lamellae. J Struct Biol. (2019) 208:107389. doi: 10.1016/j.jsb.2019.09.006

165. Pfeffer S, Woellhaf MW, Herrmann JM, Forster F. Organization of the mitochondrial translation machinery studied in situ by cryoelectron tomography. Nat Commun. (2015) 6:6019. doi: 10.1038/ncomms7019

166. Grotjahn DA, Chowdhury S, Xu Y, McKenney RJ, Schroer TA, Lander GC. Cryo-electron tomography reveals that dynactin recruits a team of dyneins for processive motility. Nat Struct Mol Biol. (2018) 25:203-7. doi: $10.1038 / \mathrm{s} 41594-018-0027-7$
167. Chakraborty S, Jasnin M, Baumeister W. Three-dimensional organization of the cytoskeleton: a cryo-electron tomography perspective. Protein Sci. (2020) 29:1302-20. doi: 10.1002/pro.3858

168. Tao CL, Liu YT, Sun R, Zhang B, Qi L, Shivakoti S, et al. Differentiation and characterization of excitatory and inhibitory synapses by cryo-electron tomography and correlative microscopy. J Neurosci. (2018) 38:1493-510. doi: 10.1523/JNEUROSCI.1548-17.2017

169. Kim SJ, Fernandez-Martinez J, Nudelman I, Shi Y, Zhang W, Raveh B, et al. Integrative structure and functional anatomy of a nuclear pore complex. Nature. (2018) 555:475-82. doi: 10.1038/nature26003

170. Tuijtel MW, Koster AJ, Jakobs S, Faas FGA, Sharp TH. Correlative cryo super-resolution light and electron microscopy on mammalian cells using fluorescent proteins. Sci Rep. (2019) 9:1369. doi: 10.1038/s41598-018-37728-8

171. Lucas MS, Gunthert M, Gasser P, Lucas F, Wepf R. Bridging microscopes: 3D correlative light and scanning electron microscopy of complex biological structures. Methods Cell Biol. (2012) 111:325-56. doi: 10.1016/B978-0-12-416026-2.00017-0

172. Moser F, Prazak V, Mordhorst V, Andrade DM, Baker LA, Hagen C, et al. Cryo-SOFI enabling low-dose super-resolution correlative light and electron cryo-microscopy. Proc Natl Acad Sci USA. (2019) 116:4804-9. doi: 10.1073/pnas.1810690116

173. Wurzer H, Hoffmann C, Al Absi A, Thomas C. Actin cytoskeleton straddling the immunological synapse between cytotoxic lymphocytes and cancer cells. Cells. (2019) 8:463. doi: 10.3390/cells8050463

174. Xu X, Xue Y, Tian B, Feng F, Gu L, Li W, et al. Ultra-stable superresolution fluorescence cryo-microscopy for correlative light and electron cryo-microscopy. Sci China Life Sci. (2018) 61:1312-19. doi: 10.1007/s11427-018-9380-3

175. Balzarotti F, Eilers Y, Gwosch KC, Gynna AH, Westphal V, Stefani FD, et al. Nanometer resolution imaging and tracking of fluorescent molecules with minimal photon fluxes. Science. (2017) 355:606-12. doi: 10.1126/science.aak 9913

176. Eilers Y, Ta H, Gwosch KC, Balzarotti F, Hell SW. MINFLUX monitors rapid molecular jumps with superior spatiotemporal resolution. Proc Natl Acad Sci USA. (2018) 115:6117-22. doi: 10.1073/pnas.1801672115

177. Gwosch KC, Pape JK, Balzarotti F, Hoess P, Ellenberg J, Ries J, et al. MINFLUX nanoscopy delivers 3D multicolor nanometer resolution in cells. Nat Methods. (2020) 17:217-24. doi: 10.1038/s41592-019-0688-0

178. Metzger H. Transmembrane signaling: the joy of aggregation. J Immunol (1992) 149:1477-87.

179. Metzger H, Alcaraz G, Hohman R, Kinet JP, Pribluda V, Quarto R. The receptor with high affinity for immunoglobulin E. Annu Rev Immunol. (1986) 4:419-70. doi: 10.1146/annurev.iy.04.040186.0 02223

180. Perez-Montfort R, Kinet JP, Metzger H. A previously unrecognized subunit of the receptor for immunoglobulin E. Biochemistry. (1983) 22:5722-8. doi: 10.1021/bi00294a007

181. Rutledge $\mathrm{T}$, Cosson P, Manolios N, Bonifacino JS, Klausner RD. Transmembrane helical interactions: zeta chain dimerization and functional association with the $\mathrm{T}$ cell antigen receptor. EMBO J. (1992) 11:3245-54. doi: 10.1002/j.1460-2075.1992.tb05402.x

182. Weissman AM, Samelson LE, Klausner RD. A new subunit of the human T-cell antigen receptor complex. Nature. (1986) 324:480-2. doi: $10.1038 / 324480 \mathrm{a} 0$

183. Call ME, Schnell JR, Xu C, Lutz RA, Chou JJ, Wucherpfennig KW. The structure of the zetazeta transmembrane dimer reveals features essential for its assembly with the T cell receptor. Cell. (2006) 127:355-68. doi: 10.1016/j.cell.2006.08.044

184. Blazquez-Moreno A, Park S, Im W, Call MJ, Call ME, Reyburn HT. Transmembrane features governing Fc receptor CD16A assembly with CD16A signaling adaptor molecules. Proc Natl Acad Sci USA. (2017) 114:E5645-54. doi: 10.1073/pnas.1706483114

185. Dong D, Zheng L, Lin J, Zhang B, Zhu Y, Li N, et al. Structural basis of assembly of the human T cell receptor-CD3 complex. Nature. (2019) 573:546-52. doi: 10.1038/s41586-019-1537-0

186. Mombaerts P, Clarke AR, Rudnicki MA, Iacomini J, Itohara S, Lafaille JJ, et al. Mutations in T-cell antigen receptor genes alpha and beta block 
thymocyte development at different stages. Nature. (1992) 360:225-31. doi: $10.1038 / 360225 \mathrm{a} 0$

187. Samelson LE. Signal transduction mediated by the $\mathrm{T}$ cell antigen receptor: the role of adapter proteins. Annu Rev Immunol. (2002) 20:371-94. doi: 10.1146/annurev.immunol.20.092601.111357

188. Ferrao RD, Wallweber HJ, Lupardus PJ. Receptor-mediated dimerization of JAK2 FERM domains is required for JAK2 activation. Elife. (2018) 7:e38089. doi: 10.7554/eLife.38089

189. Boggon TJ, Eck MJ. Structure and regulation of Src family kinases. Oncogene. (2004) 23:7918-27. doi: 10.1038/sj.onc.1208081

190. Korade-Mirnics Z, Corey SJ. Src kinase-mediated signaling in leukocytes. $J$ Leukoc Biol. (2000) 68:603-13. doi: 10.1189/jlb.68.5.603

191. Spassov DS, Ruiz-Saenz A, Piple A, Moasser MM. A dimerization function in the intrinsically disordered N-terminal region of src. Cell Rep. (2018) 25:449-63.e4. doi: 10.1016/j.celrep.2018.09.035

192. Chini CC, Leibson PJ. Signal transduction during natural killer cell activation. Curr Protoc Immunol. (2001) 11:Unit 11 9B. doi: 10.1002/0471142735.im1109bs35

193. Sanchez-Mejorada G, Rosales C. Signal transduction by immunoglobulin Fc receptors. J Leukocyte Biol. (1998) 63:521-33. doi: 10.1002/jlb.6 3.5.521

194. Watzl C, Long EO. Signal transduction during activation and inhibition of natural killer cells. Curr Protoc Immunol. (2010) 11:Unit 11 9B. doi: 10.1002/0471142735.im1109bs90

195. Vargas-Hernandez A, Forbes LR. JAK/STAT proteins and their biological impact on NK cell development and function. Mol Immunol. (2019) 115:2130. doi: 10.1016/j.molimm.2018.12.005

196. Costanzo MC, Kim D, Creegan M, Lal KG, Ake JA, Currier JR, et al. Transcriptomic signatures of NK cells suggest impaired responsiveness in HIV-1 infection and increased activity post-vaccination. Nat Commun. (2018) 9:1212. doi: 10.1038/s41467-018-03618-w

197. Sezgin E, Levental I, Mayor S, Eggeling C. The mystery of membrane organization: composition, regulation and roles of lipid rafts. Nat Rev Mol Cell Biol. (2017) 18:361-74. doi: 10.1038/nrm.2017.16

198. Harayama T, Riezman H. Understanding the diversity of membrane lipid composition. Nat Rev Mol Cell Biol. (2018) 19:281-96. doi: 10.1038/nrm.2017.138

199. Bournazos S, Hart SP, Chamberlain LH, Glennie MJ, Dransfield I. Association of FcgammaRIIa (CD32a) with lipid rafts regulates ligand binding activity. J Immunol. (2009) 182:8026-36. doi: 10.4049/jimmunol.0900107

200. Dykstra M, Cherukuri A, Sohn HW, Tzeng SJ, Pierce SK. Location is everything: lipid rafts and immune cell signaling. Annu Rev Immunol. (2003) 21:457-81. doi: 10.1146/annurev.immunol.21.120601.141021

201. Katagiri YU, Kiyokawa N, Fujimoto J. A role for lipid rafts in immune cell signaling. Microbiol Immunol. (2001) 45:1-8. doi: 10.1111/j.1348-0421.2001.tb01259.x

202. Munro S. Lipid rafts: elusive or illusive? Cell. (2003) 115:377-88. doi: 10.1016/S0092-8674(03)00882-1

203. Zurzolo C, Simons K. Glycosylphosphatidylinositol-anchored proteins: membrane organization and transport. Biochim Biophys Acta. (2016) 1858:632-9. doi: 10.1016/j.bbamem.2015.12.018

204. Cecchetti S, Spadaro F, Lugini L, Podo F, Ramoni C. Functional role of phosphatidylcholine-specific phospholipase C in regulating CD16 membrane expression in natural killer cells. Eur J Immunol. (2007) 37:291222. doi: 10.1002/eji.200737266

205. Fassett MS, Davis DM, Valter MM, Cohen GB, Strominger JL. Signaling at the inhibitory natural killer cell immune synapse regulates lipid raft polarization but not class I MHC clustering. Proc Natl Acad Sci USA. (2001) 98:14547-52. doi: 10.1073/pnas.211563598

206. Masilamani M, Nguyen C, Kabat J, Borrego F, Coligan JE. CD94/NKG2A inhibits NK cell activation by disrupting the actin network at the immunological synapse. J Immunol. (2006) 177:3590-6. doi: 10.4049/jimmunol.177.6.3590

207. Sanni TB, Masilamani M, Kabat J, Coligan JE, Borrego F. Exclusion of lipid rafts and decreased mobility of CD94/NKG2A receptors at the inhibitory NK cell synapse. Mol Biol Cell. (2004) 15:3210-23. doi: 10.1091/mbc.e03-1 $1-0779$
208. Watzl C, Long EO. Natural killer cell inhibitory receptors block actin cytoskeleton-dependent recruitment of 2B4 (CD244) to lipid rafts. J Exp Med. (2003) 197:77-85. doi: 10.1084/jem.20020427

209. Qin WH, Yang ZS, Li M, Chen Y, Zhao XF, Qin YY, et al. High serum levels of cholesterol increase antitumor functions of nature killer cells and reduce growth of liver tumors in mice. Gastroenterology. (2020) 158:1713-27. doi: 10.1053/j.gastro.2020.01.028

210. Filatova NA, Chubinskii-Nadezhdin VI, Ivanov VA, Morachevskaia EA. [Sensitivity to lysis by natural killers depends on the integrity of lipid rafts in plasma membrane of transformed cells]. Tsitologiia. (2010) 52:983-9. doi: 10.1134/S1990519X11010068

211. Birnbaum ME, Berry R, Hsiao YS, Chen Z, Shingu-Vazquez MA, Yu X, et al. Molecular architecture of the alphabeta $\mathrm{T}$ cell receptor-CD3 complex. Proc Natl Acad Sci USA. (2014) 111:17576-81. doi: 10.1073/pnas.1420936111

212. Cai H, Muller J, Depoil D, Mayya V, Sheetz MP, Dustin ML, et al. Full control of ligand positioning reveals spatial thresholds for $\mathrm{T}$ cell receptor triggering. Nat Nanotechnol. (2018) 13:610-17. doi: 10.1038/s41565-018-0113-3

213. Call ME, Wucherpfennig KW, Chou JJ. The structural basis for intramembrane assembly of an activating immunoreceptor complex. Nat Immunol. (2010) 11:1023-9. doi: 10.1038/ni.1943

214. Courtney AH, Lo WL, Weiss A. TCR signaling: mechanisms of initiation and propagation. Trends Biochem Sci. (2018) 43:108-23. doi: 10.1016/j.tibs.2017.11.008

215. Goyette J, Nieves DJ, Ma YQ, Gaus K. How does T cell receptor clustering impact on signal transduction? J Cell Sci. (2019) 132:jcs226423. doi: $10.1242 /$ jcs. 226423

216. Pielak RM, O’Donoghue GP, Lin JJ, Alfieri KN, Fay NC, Low-Nam ST, et al. Early $\mathrm{T}$ cell receptor signals globally modulate ligand:receptor affinities during antigen discrimination. Proc Natl Acad Sci USA. (2017) 114:12190-5. doi: $10.1073 /$ pnas. 1613140114

217. Volkman BF, Lipson D, Wemmer DE, Kern D. Two-state allosteric behavior in a single-domain signaling protein. Science. (2001) 291:2429-33. doi: $10.1126 /$ science. 291.5512 .2429

218. Reinherz EL. The structure of a T-cell mechanosensor. Nature. (2019) 573:502-4. doi: 10.1038/d41586-019-02646-w

219. Sherman E, Barr V, Manley S, Patterson G, Balagopalan L, Akpan I, et al. Functional nanoscale organization of signaling molecules downstream of the T cell antigen receptor. Immunity. (2011) 35:705-20. doi: 10.1016/j.immuni.2011.10.004

220. Razvag Y, Neve-Oz Y, Sajman J, Reches M, Sherman E. Nanoscale kinetic segregation of TCR and CD45 in engaged microvilli facilitates early T cell activation. Nat Commun. (2018) 9:732. doi: 10.1038/s41467-018-03127-w

221. Blanco R, Alarcon B. TCR nanoclusters as the framework for transmission of conformational changes and cooperativity. Front Immunol. (2012) 3:115. doi: 10.3389/fimmu.2012.00115

222. Neve-Oz Y, Razvag Y, Sajman J, Sherman E. Mechanisms of localized activation of the $\mathrm{T}$ cell antigen receptor inside clusters. Biochim Biophys Acta. (2015) 1853:810-21. doi: 10.1016/j.bbamcr.2014.09.025

223. Pageon SV, Tabarin T, Yamamoto Y, Ma Y, Nicovich PR, Bridgeman JS, et al. Functional role of T-cell receptor nanoclusters in signal initiation and antigen discrimination. Proc Natl Acad Sci USA. (2016) 113:E5454-63. doi: 10.1073/pnas. 1607436113

224. Sherman E, Barr V, Samelson LE. Super-resolution characterization of TCR-dependent signaling clusters. Immunol Rev. (2013) 251:21-35. doi: $10.1111 /$ imr. 12010

225. Hu YS, Cang H, Lillemeier BF. Superresolution imaging reveals nanometer- and micrometer-scale spatial distributions of T-cell receptors in lymph nodes. Proc Natl Acad Sci USA. (2016) 113:7201-6. doi: 10.1073/pnas.1512331113

226. Friedl P, den Boer AT, Gunzer M. Tuning immune responses: diversity and adaptation of the immunological synapse. Nat Rev Immunol. (2005) 5:532-45. doi: $10.1038 /$ nri1647

227. Hsu CJ, Baumgart T. Spatial association of signaling proteins and F-actin effects on cluster assembly analyzed via photoactivation localization microscopy in T cells. PLoS ONE. (2011) 6:e23586. doi: 10.1371/journal.pone.0023586

228. Wines BD, Vanderven HA, Esparon SE, Kristensen AB, Kent SJ, Hogarth PM. Dimeric FcgammaR ectodomains as probes of the Fc receptor 
function of anti-influenza virus IgG. J Immunol. (2016) 197:1507-16. doi: 10.4049/jimmunol.1502551

229. Jiang GQ, Hunter T. Receptor signaling: when dimerization is not enough. Curr Biol. (1999) 9:R568-71. doi: 10.1016/S0960-9822(99)80357-1

230. Moraga I, Wernig G, Wilmes S, Gryshkova V, Richter CP, Hong WJ, et al. Tuning cytokine receptor signaling by re-orienting dimer geometry with surrogate ligands. Cell. (2015) 160:1196-208. doi: 10.1016/j.cell.2015.02.011

231. Pang X, Zhou HX. Activation of signaling receptors: do ligands bind to receptor monomer, dimer, or both? BMC Biophys. (2013) 6:7. doi: 10.1186/2046-1682-6-7

232. Stock J. Receptor signaling: dimerization and beyond. Curr Biol. (1996) 6:825-7. doi: 10.1016/S0960-9822(02)00605-X

233. Maruyama IN. Activation of transmembrane cell-surface receptors via a common mechanism? The "rotation model". Bioessays. (2015) 37:959-67. doi: 10.1002/bies.201500041

234. Botos I, Segal DM, Davies DR. The structural biology of Toll-like receptors. Structure. (2011) 19:447-59. doi: 10.1016/j.str.2011.02.004

235. Powell MS, Barnes NC, Bradford TM, Musgrave IF, Wines BD, Cambier JC, et al. Alteration of the Fc gamma RIIa dimer interface affects receptor signaling but not ligand binding. J Immunol. (2006) 176:7489-94. doi: 10.4049/jimmunol.176.12.7489

236. Ramsland PA, Farrugia W, Bradford TM, Sardjono CT, Esparon S, Trist $\mathrm{HM}$, et al. Structural basis for Fc gammaRIIa recognition of human IgG and formation of inflammatory signaling complexes. J Immunol. (2011) 187:3208-17. doi: 10.4049/jimmunol.1101467

237. Elvington M, Liszewski MK, Atkinson JP. Evolution of the complement system: from defense of the single cell to guardian of the intravascular space. Immunol Rev. (2016) 274:9-15. doi: 10.1111/imr.12474

238. Reis ES, Mastellos DC, Hajishengallis G, Lambris JD. New insights into the immune functions of complement. Nat Rev Immunol. (2019) 19:503-16. doi: 10.1038/s41577-019-0168-x

239. Diebolder CA, Beurskens FJ, de Jong RN, Koning RI, Strumane K, Lindorfer MA, et al. Complement is activated by IgG hexamers assembled at the cell surface. Science. (2014) 343:1260-63. doi: 10.1126/science.1248943

240. Sharp TH, Boyle AL, Diebolder CA, Kros A, Koster AJ, Gros P. Insights into IgM-mediated complement activation based on in situ structures of IgM-C1-C4b. Proc Natl Acad Sci USA. (2019) 116:11900-05. doi: 10.1073/pnas.1901841116

241. Ugurlar D, Howes SC, de Kreuk BJ, Koning RI, de Jong RN, Beurskens FJ, et al. Structures of C1-IgG1 provide insights into how danger pattern recognition activates complement. Science. (2018) 359:794-7. doi: $10.1126 /$ science.aao4988

242. Saphire EO, Parren PW, Pantophlet R, Zwick MB, Morris GM, Rudd PM, et al. Crystal structure of a neutralizing human IGG against HIV-1: a template for vaccine design. Science. (2001) 293:1155-9. doi: $10.1126 /$ science. 1061692

243. Gaboriaud C, Thielens NM, Gregory LA, Rossi V, Fontecilla-Camps JC, Arlaud GJ. Structure and activation of the C1 complex of complement: unraveling the puzzle. Trends Immunol. (2004) 25:368-73. doi: 10.1016/j.it.2004.04.008

244. Roux KH, Strelets L, Michaelsen TE. Flexibility of human IgG subclasses. $J$ Immunol. (1997) 159:3372-82.

245. Sandin S, Ofverstedt LG, Wikstrom AC, Wrange O, Skoglund U. Structure and flexibility of individual immunoglobulin $\mathrm{G}$ molecules in solution. Structure. (2004) 12:409-15. doi: 10.1016/j.str.2004.02.011

246. Czajkowsky DM, Shao Z. The human IgM pentamer is a mushroom-shaped molecule with a flexural bias. Proc Natl Acad Sci USA. (2009) 106:14960-5. doi: 10.1073/pnas. 0903805106

247. Kumar N, Arthur CP, Ciferri C, Matsumoto ML. Structure of the secretory immunoglobulin A core. Science. (2020) 367:1008-14. doi: $10.1126 /$ science.aaz5807

248. Rouge L, Chiang N, Steffek M, Kugel C, Croll TI, Tam C, et al. Structure of CD20 in complex with the therapeutic monoclonal antibody rituximab. Science. (2020) 367:1224-30. doi: 10.1126/science.aaz9356

249. Oyen D, Torres JL, Cottrell CA, Richter King C, Wilson IA, Ward AB. CryoEM structure of $\mathrm{P}$. falciparum circumsporozoite protein with a vaccineelicited antibody is stabilized by somatically mutated inter-Fab contacts. Sci Adv. (2018) 4:eaau8529. doi: 10.1126/sciadv.aau8529
250. Yang D, Kroe-Barrett R, Singh S, Roberts CJ, Laue TM. IgG cooperativity - is there allostery? Implications for antibody functions and therapeutic antibody development. Mabs-Austin. (2017) 9:1231-52. doi: 10.1080/19420862.2017.1367074

251. Bowen A, Casadevall A. Revisiting the immunoglobulin intramolecular signaling hypothesis. Trends Immunol. (2016) 37:721-3. doi: 10.1016/j.it.2016.08.014

252. Guddat LW, Shan L, Fan ZC, Andersen KN, Rosauer R, Linthicum DS, et al. Intramolecular signaling upon complexation. FASEB J. (1995) 9:101-6. doi: 10.1096/fasebj.9.1.7821748

253. Jagusiak A, Konieczny L, Krol M, Marszalek P, Piekarska B, Piwowar P, et al. Intramolecular immunological signal hypothesis revived-structural background of signalling revealed by using congo Red as a specific tool. Mini Rev Med Chem. (2015) 14:1104-13. doi: $10.2174 / 1389557514666141127150803$

254. Zhao J, Nussinov R, Ma B. Antigen binding allosterically promotes Fc receptor recognition. MAbs-Austin. (2019) 11:58-74. doi: 10.1080/19420862.2018.1522178

255. Sela-Culang I, Alon S, Ofran Y. A systematic comparison of free and bound antibodies reveals binding-related conformational changes. J Immunol. (2012) 189:4890-9. doi: 10.4049/jimmunol.1201493

256. Su CTT, Lua WH, Ling WL, Gan SKE. Allosteric effects between the antibody constant and variable regions: a study of IgA Fc mutations on antigen binding. Antibodies. (2018) 7:20. doi: 10.3390/antib7020020

257. Lua WH, Ling WL, Yeo JY, Poh JJ, Lane DP, Gan SK. The effects of antibody engineering $\mathrm{CH}$ and $\mathrm{CL}$ in trastuzumab and pertuzumab recombinant models: impact on antibody production and antigen-binding. Sci Rep. (2018) 8:718. doi: 10.1038/s41598-018-29097-z

258. Bournazos S, Klein F, Pietzsch J, Seaman MS, Nussenzweig MC, Ravetch JV. Broadly neutralizing anti-HIV-1 antibodies require Fc effector functions for in vivo activity. Cell. (2014) 158:1243-53. doi: 10.1016/j.cell.2014.08.023

259. Strasser J, de Jong RN, Beurskens FJ, Wang GB, Heck AJR, Schuurman J, et al.Parren WHI, Hinterdorfer P, Preiner J. Unraveling the macromolecular pathways of IgG oligomerization and complement activation on antigenic surfaces. Nano Lett. (2019) 19:4787-96. doi: 10.1021/acs.nanolett.9b02220

260. Wang G, de Jong RN, van den Bremer ET, Beurskens FJ, Labrijn AF, Ugurlar D, et al. Molecular basis of assembly and activation of complement component $\mathrm{C} 1$ in complex with immunoglobulin G1 and antigen. Mol Cell. (2016) 63:135-45. doi: 10.1016/j.molcel.2016.05.016

261. Su B, Dispinseri S, Iannone V, Zhang T, Wu H, Carapito R, et al. Update on Fc-mediated antibody functions against HIV-1 beyond neutralization. Front Immunol. (2019) 10:2968. doi: 10.3389/fimmu.2019.02968

262. Boudreau CM, Alter G. Extra-neutralizing FcR-mediated antibody functions for a universal influenza vaccine. Front Immunol. (2019) 10:440. doi: 10.3389/fimmu.2019.00440

263. Leon PE, He W, Mullarkey CE, Bailey MJ, Miller MS, Krammer F, et al. Optimal activation of Fc-mediated effector functions by influenza virus hemagglutinin antibodies requires two points of contact. Proc Natl Acad Sci USA. (2016) 113:E5944-51. doi: 10.1073/pnas.16132 25113

264. Bournazos S, DiLillo DJ, Goff AJ, Glass PJ, Ravetch JV. Differential requirements for FcgammaR engagement by protective antibodies against Ebola virus. Proc Natl Acad Sci USA. (2019) 116:20054-62. doi: 10.1073/pnas.1911842116

265. Yadav SP. The wholeness in suffix -omics, -omes, and the word om. J Biomol Tech. (2007) 18:277.

266. Misra BB, Langefeld CD, Olivier M, Cox LA. Integrated omics: tools, advances, future approaches. J Mol Endocrinol. (2018) 62:JME-18-0055. doi: 10.1530/JME-18-0055

267. Westerhoff HV, Palsson BO. The evolution of molecular biology into systems biology. Nat Biotechnol. (2004) 22:1249-52. doi: 10.1038/nbt1020

268. Zhou Y, Xu X, Tian Z, Wei H. "Multi-Omics" analyses of the development and function of natural killer cells. Front Immunol. (2017) 8:1095. doi: 10.3389/fimmu.2017.01095

269. Yang C, Siebert JR, Burns R, Gerbec ZJ, Bonacci B, Rymaszewski A, et al. Heterogeneity of human bone marrow and blood natural killer cells defined by single-cell transcriptome. Nat Commun. (2019) 10:3931. doi: 10.1038/s41467-019-11947-7 
270. Crinier A, Milpied P, Escaliere B, Piperoglou C, Galluso J, Balsamo A, et al. High-dimensional single-cell analysis identifies organ-specific signatures and conserved NK cell subsets in humans and mice. Immunity. (2018) 49:971-86.e5. doi: 10.1016/j.immuni.2018.09.009

271. Roederer M, Quaye L, Mangino M, Beddall MH, Mahnke Y, Chattopadhyay $\mathrm{P}$, et al. The genetic architecture of the human immune system: a bioresource for autoimmunity and disease pathogenesis. Cell. (2015) 161:387-403. doi: 10.1016/j.cell.2015.02.046

272. Monaco G, Lee B, Xu W, Mustafah S, Hwang YY, Carre C, et al. RNA-Seq signatures normalized by mRNA abundance allow absolute deconvolution of human immune cell types. Cell Rep. (2019) 26:1627-40.e7. doi: 10.1016/j.celrep.2019.01.041

273. Rolle A, Brodin P. Immune adaptation to environmental influence: the case of NK cells and HCMV. Trends Immunol. (2016) 37:233-43. doi: 10.1016/j.it.2016.01.005

274. Ma D, Cao W, Kapur A, Felder M, Scarlett CO, Patankar MS, et al. Differential expression of proteins in naive and IL-2 stimulated primary human NK cells identified by global proteomic analysis. J Proteomics. (2013) 91:151-63. doi: 10.1016/j.jprot.2013.06.024

275. Korenevskii AV, Milyutina YP, Zhdanova AA, Pyatygina KM, Sokolov DI, Sel'kov SA. Mass-spectrometric analysis of proteome of microvesicles produced by NK-92 natural killer cells. Bull Exp Biol Med. (2018) 165:564-71. doi: 10.1007/s10517-018-4214-7

276. Hanna J, Fitchett J, Rowe T, Daniels M, Heller M, Gonen-Gross T, et al. Proteomic analysis of human natural killer cells: insights on new potential NK immune functions. Mol Immunol. (2005) 42:425-31. doi: 10.1016/j.molimm.2004.07.022

277. Voigt J, Malone DFG, Dias J, Leeansyah E, Bjorkstrom NK, Ljunggren HG, et al. Proteome analysis of human CD56(neg) NK cells reveals a homogeneous phenotype surprisingly similar to CD56(dim) NK cells. Eur J Immunol. (2018) 48:1456-69. doi: 10.1002/eji.201747450

278. Rautela J, Dagley LF, de Oliveira CC, Schuster IS, Hediyeh-Zadeh S, Delconte RB, et al. Therapeutic blockade of activin-A improves NK cell function and antitumor immunity. Sci Signal. (2019) 12:eaat7527. doi: 10.1126/scisignal.aat7527

279. Gardiner CM, Finlay DK. What fuels natural killers? Metabolism and NK cell responses. Front Immunol. (2017) 8:367. doi: 10.3389/fimmu.2017.00367

280. O'Brien KL, Finlay DK. Immunometabolism and natural killer cell responses. Nat Rev Immunol. (2019) 19:282-90. doi: 10.1038/s41577-019-0139-2

281. Pinu FR, Beale DJ, Paten AM, Kouremenos K, Swarup S, Schirra $\mathrm{HJ}$, et al. Systems biology and multi-omics integration: viewpoints from the metabolomics research community. Metabolites. (2019) 9:76. doi: 10.3390/metabo9040076

282. Poznanski SM, Ashkar AA. What defines NK cell functional fate: phenotype or metabolism? Front Immunol. (2019) 10:1414. doi: 10.3389/fimmu.2019.01414

Conflict of Interest: The author declares that the research was conducted in the absence of any commercial or financial relationships that could be construed as a potential conflict of interest.

Copyright $(\odot) 2020$ Murin. This is an open-access article distributed under the terms of the Creative Commons Attribution License (CC BY). The use, distribution or reproduction in other forums is permitted, provided the original author(s) and the copyright owner(s) are credited and that the original publication in this journal is cited, in accordance with accepted academic practice. No use, distribution or reproduction is permitted which does not comply with these terms. 